\title{
Bitlis Kalesi Osmanlı Dönemi Lülelerinin Değerlendirilmesi (2018 Yılı Kazı Sezonu)
}

\section{An Evaluation of the Ottoman-Period Pipes in Bitlis Castle (2018 Excavation Seasion)}

\author{
Korkmaz Şen* $\odot$, Yunus Emre Karasu* $\odot$
}

\section{Öz}

Bitlis ilinin merkezinde kayalık bir alan üzerinde yer alan Bitlis Kalesi'nde 2018 yılı kazı çalışmalarında ele geçirilen lüle buluntuları çalışmamızda incelenecektir. 2018 yılında Bitlis Kalesi'nde yapılan çalışmalarda P ve R 14-15 olarak isimlendirilen alanlarda ve sondajda çok sayıda farklı form ve bezeme özelliklerine sahip lüle buluntularına ulaşılmıştır. Bu lüle buluntuları içerisinde kaideli, süzgeçli çanaklı lüleler ayrıca ele alındığı için çalışma konumuzun dışında tutulmuştur. Osmanlı Devleti’nde genellikle sosyalleşme mekânı olan kahvehanelerde kahve ile birlikte tütün içmek için kullanılan lüleler, tütün üretimi yapıldığı bilinen Bitlis’te de yoğun şekilde görülmektedir. Bitlis Kalesi'nde yapılan kazı çalışmaları sırasında ele geçirilen lüle buluntularının çeşitliliği ve çokluğu da bölgede yoğun lüle kullanımını göstermektedir. Form, boyut, katkı ve bezeme özellikleri bakımından farklı dönem özellikleri gösteren lülelerin tütün dışında farklı bitkiler için kullanıldığı da bilinmektedir. Lüle form ve çeşitlerinin yerel beğenilerin yanı sıra işlevsel amaçlarına göre farklılıklar gösterdiği de düşünülmektedir. Konumuzu oluşturan lüle buluntuları, kazı çalışmalarında ele geçirilen diğer veriler ve Anadolu'daki benzer örnekleri ile karşılaştırıldığında 17-19. yüzyıl arasına tarihlendirilmektedir.

Anahtar Kelimeler

Bitlis Kalesi, Osmanlı Devleti, Lüle, Kazı, Tütün

\section{Abstract}

This study's aim was to examine pipes, found in excavation works in 2018 in Bitlis Castle, which is located on a rocky region in the city centre of the Bitlis province. Pipe finds with a large number of different forms and decoration features were obtained in areas, called P and R 14-15 and a drilling in the excavation works in Bitlis Castle in 2018. As a base, out of these pipe finds sieve bowl pipes were examined in an earlier published study so they are excluded from the present one. Pipes, which were used to smoke along with coffee in coffeehouses, generally the socialization spaces in the Ottoman Empire, were also widely used in Bitlis, where tobacco was known to have been produced. The variety and abundance of pipe finds found during excavation works in Bitlis Castle indicate that pipes were used in the region to a high degree. Moreover, it is understood that different plants were used to smoke except for pipes, having distinct period characteristics in terms of form, size, additive, and decoration features. It is considered that pipe forms and types vary by local tastes and functional purpose. When pipe finds, composing the subject matter of the present study, are compared to other data collected in excavation works, and their similar samples, they may be dated to a period between the $17^{\text {th }}$ and $19^{\text {th }}$ centuries.

\section{Keywords}

Bitlis Castle, the Ottoman State, Pipe, Excavation, Tobacco

* Sorumlu Yazar: Korkmaz Şen (Dr. Öğr. Üyesi), Fırat Üniversitesi, İnsani ve Sosyal Bilimler Fakültesi, Arkeoloji Bölümü, Elazığ, Türkiye. E-posta: ksen@firat.edu.tr ORCID: 0000-0003-4332-7567

** Yunus Emre Karasu (Arş. Gör.), Bitlis Eren Üniversitesi, Fen-Edebiyat Fakültesi, Sanat Tarihi Bölümü, Bitlis, Türkiye. E-posta: yekarasu@beu.edu.tr ORCID: 0000-0001-9604-6510

Atıf: Sen, Korkmaz ve Karasu, Yunus Emre. “Bitlis Kalesi Osmanlı Dönemi Lülelerinin Değerlendirilmesi (2018 Yılı Kazı Sezonu)." Art-Sanat, 14(2020): 413-440. https://doi.org/10.26650/artsanat.2020.14.0016 


\section{Extended Summary}

Bitlis Castle is located in the center of the Bitlis province within the borders of the Eastern Anatolia Region. The Iskender Stream to its west and The Dideban Stream to its east form a natural moat around the castle on a rocky hill, which is higher than its surroundings dominating the region.

Pipe finds, which were obtained in excavation works in Bitlis Castle in 2018, will be examined and evaluated within the scope of the present study. Pipe finds in a large number of different forms and decoration features were obtained in the areas, called P and R 14-15 and a drilling in excavation works in Bitlis Castle in 2018. As a base, out of these pipe finds sieve bowl pipes were examined in an earlier published study, so they were excluded from the present one.

The most common groups of forms were comprised of sieve and non-sieve shallow rounded bowl pipes in the Bitlis Castle excavation in 2018. In addition to these groups, pipe samples with forms of disc bowl, round bowl, biconical bowl, lily bowl, sack-shaped bowl, cylinder bowl, and a great number of pipe finds only with flue were also found. Pipe finds in different forms were largely of clean paste, little and smallsized additive, and they were a little porous and hard-baked. The pipes, examined in the present study consist of 113 finds in total, including sieve, shallow rounded bowl pipes ( 24 pieces), disc bowl pipes ( 5 pieces), round bowl pipes ( 22 pieces), biconical bowl pipes ( 7 pieces), lily bowl pipes ( 3 pieces), sack-shaped bowl pipes ( 9 pieces), cylinder bowl pipes ( 3 pieces), shallow round base pipes ( 1 piece), and the pipes only with flue (32 pieces).

Besides these, a find, which was not examined in existing publications, and which is considered to be a cup for embers as may be inferred from coal dust and burns was also revealed. Some additives such as mica, lime, sand, and fireclay exist in the pastes of the examined pipes. The pipe pastes were in red, grey, pink, and brown with white colours having different tones of the mentioned colours. Different decoration techniques such as incised, imprint, roulette, and molding were applied on the pipes singly or along with a few of them. In addition to pipe finds; coffee cups, ceramic pieces, metal objects, and coins were also found in both exposals of the spaces. The place where a great number of finds, belonging to daily life, were attained, is considered to have been used as a public space. It is known that people used to go to coffeehouses after hammams in the Ottoman period. It is indicated that these places might have been used as coffeehouses as they were situated in the south of the castle near the hammam and particularly as pipes and coffee cups were intensively found. A space, which is considered to be a palace, and a hammam were found in the excavation conducted in Bitlis Castle today. The space, which was built with mortarless dry walls, is considered to belong to the $18^{\text {th }}$ and $19^{\text {th }}$ centuries. Some finds, which are considerably 
significant in terms of the history of Bitlis Castle, were detected in the drilling work in the excavation area. The entire discontinuance of pipe finds after reaching a definite depth in the drilling work provides notably important data in terms of dating.

Black, glazed sieve, shallow round bowl pipes and large-sized, red-lined, glazed disc sieve and lily bowl pipes were found right after digging approximately $20 \mathrm{~cm}$ in the exposals in the excavation; thus, the pipe finds, obtained in that section, which was a late Ottoman settlement, are dated to the $19^{\text {th }}$ century which it is known to have been the last settlement in the castle. It is noted in the English consul J. Brant's reports that the castle was brought into total use in 1836. One of the reasons for dating the pipes to the $19^{\text {th }}$ century is that there were not any other available pipe finds following the similar samples in different areas and a 1810-11-dated coin, belonging to the period of Mahmut II.

The pipes that mainly belonged to the $18^{\text {th }}$ century was sack-shaped bowl, biconical, shallow round bowl pipes and additionally, 1701-1702-dated Mustafa II-period, 1737-1741-dated Mahmoud I-period, 1788-dated Abdulhamid I-period coins were obtained. However, out of these pipe types, the ones with a paste colour in oyster white tones were attained in deeper parts than other pipe finds, predominantly in the drilling section, and they are considered to belong to the period between the $17^{\text {th }}$ century and the first quarter of $18^{\text {th }}$ century as the coin, found with the pipes, could not be read because of corrosion. Although obtaining coins along with the pipes provides significant data for dating, it became difficult to date the pipes more precisely because the coins were in juxtaposition and most of them could not be read because of corrosion. Besides the coins, many coffee cups obtained also confirmed the existing data. Apart from black pipe finds, the other samples, which are similar in terms of both form and decoration, were widely seen in Anatolia and out of Anatolia, thus indicating that only black glazed pipe finds, found out in Bitlis Castle, were local production and that the other samples, belonging to the $17^{\text {th }}-19^{\text {th }}$ centuries, were imported to the region through trade. In relation to Bitlis castle excavation pipes of the year 2018, it is noted that other finds besides pipes, obtained in two exposals covering a limited part of the excavation area of the drilling work support each other. A part of the area presents stratigraphically explicit data and permits the finds to be more precisely dated. The excavation work in Bitlis Castle in the forthcoming years will provide a significant contribution to a more extensive evaluation of the excavation work area and particularly pipes by means of stratigraphical data. 


\section{Giriş}

Osmanlı döneminde tütün ve lülenin yoğun talep gördüğü bilinmektedir. 1543 y1lında kahve, 1601 yılında tütünün Osmanlı topraklarına girmesiyle birlikte bu ürünler kısa sürede benimsenip Anadolu'da yayılmaya başlamıştır. ${ }^{1}$ Afyon, haşhaş ve 17. yüzyıldan itibaren tütünün Osmanlı topraklarında oldukça yoğun şekilde kullanıldığ bilinmektedir. ${ }^{2} \mathrm{Bu}$ yoğun kullanım sonucunda I. Ahmet (1603-1617), II. Osman (1618-1622) ve IV. Murat dönemlerinde tütün kullanımı yasaklanmıştır. ${ }^{3}$

Lüle, Osmanlı coğrafyasında oldukça yaygın ve yoğun şekilde görülmekle birlikte Osmanlı merasimlerinde gelen misafire lüle, çubuk ve kehribar imameden oluşan çubuk 1smarlanarak ikramda bulunulduğu, tütünü yakarken fazla üflemek ve duman savurmanın ise ayıp karşılandığı bilinmektedir. ${ }^{4}$ 18. yüzyılda tütün ve kahvenin tüketildiği kahvehaneler, Osmanlı şehirlerinde önemli sosyalleşme mekânları olmakta, çok sayıda lüleci ve çubukçu dükkanı da bulunmaktadır. ${ }^{5}$ Ayrıca 18 . yüzyıla gelindiğinde İstanbul'da tütüncü dükkanı sayısında da büyük bir artış görülmektedir. ${ }^{6}$ Tütünün yaygın kullanımı sonucunda lüle, pipo, enfiye kutusunun kalitesi ve üzerinde yer alan bezemeler kullanan kişinin sosyal statüsünü belirtir hâle gelmiştir.?

Bitlis Kale kazısında ele geçirilen çok sayıda lüle buluntusu Osmanlı döneminde bölgede yoğun tütün ve lüle kullanımını göstermekte ve dönemin genel yapısını yansitmaktadır. 1751 tarihinde yazılan Tahlilu'd-Duhan adlı risalede Nu'man Efendi kokusunu en çok beğendiği tütünlerden birisinin Bitlis'in Şetek bölgesinde yetiştirildiğini belirtmektedir. ${ }^{8}$ Tütün üretimi olduğu anlaşılan bölgede lüle üretiminin de yapıldığı düşünülmektedir. ${ }^{9}$ Ayrıca Osmanlı'da tütün lülelerinin yapımında kullanılan lüle toprağının \%12 kuruş vergi karşıllı̆ında belli süreliğine yabancı tüccarlara satıl-

1 Raphaela Lewis, Osmanlı Türkiyesinde Gündelik Hayat (âdetler ve gelenekler), çev. Mefkure Poroy (İstanbul: Doğan Kardeş Yayınları, 1973), 144.

2 Miri Shefer Mossensohn, Osmanlı Tibbl: Tedavi ve Tıbbi Kurumları (1500-1700), çev. Bülent Üçpunar, (İstanbul: Kitap Yayınevi, 2014), 71.

3 Metin Ünal, “Tütünün Dört Yüz Y1lı”, Tütün Kitabl, ed. Emine Gürsoy Naskali (İstanbul: Kitabevi, 2003), 17 .

4 Abdülaziz Bey, Osmanlı Âdet, Merasim ve Tabirleri: Toplum Hayatı, haz. Kazım Arısan ve Duygu Arısan Günay, (İstanbul: Türkiye Ekonomik ve Toplumsal Tarih Vakfi, 1995), 45-46.

5 Cengiz Kırlı ve Betül Başaran, “18. Yüzyıl Sonlarında Osmanlı Esnafı", Osmanlı'dan Cumhuriyet'e Esnaf ve Ticaret, der. Fatmagül Demirel (İstanbul: Tarih Vakfı Yurt Yayınları, 2012), 15-16.

6 Fehmi Yılmaz, “İstanbul'da Tütüncü Esnafi”, Osmanlı'dan Cumhuriyet'e Esnaf ve Ticaret, der. Fatmagül Demirel (İstanbul: Tarih Vakfi Yurt Yayınları, 2012), 132-134.

7 Fehmi Yılmaz, "Tütün Üzerine Düşünceler: Batıda ve Bizde”, Tütün Kitabı. ed. Emine Gürsoy Naskali (İstanbul: Kitabevi, 2003), 7.

8 Mehmet Kalaycı ve Eyüp Öztürk, "18. Yüzyıl Osmanlı Coğrafyasında Tütünün Sosyo-Kültürel Zeminine Dair Bir Metin: Ebu Sehl Nu'man Efendi ve Tahlılu'd-Duhan Adlı Risalesi”, Ankara Üniversitesi Illahiyat Fakültesi Dergisi 58:1 (2017), 15, 22.

9 Lüle üretimine dair buluntular için bkz. Korkmaz Sen ve Yunus Emre Karasu, "2018 Yılı Bitlis Kale Kazısı Kaideli, Süzgeçli Çanaklı Lüle Buluntuları”, Atatürk Üniversitesi Türkiyat Araștırmaları Enstitüsü Dergisi 65 (2019), 189-206. 
mak suretiyle ihracatının gerçekleştirildiği bilinmektedir. Özellikle Bosna eyaletinin Benaluka sancağı ile Eskişehir bu anlamda önem kazanmıştır. ${ }^{10}$

\section{Bitlis Kale Kazısı ${ }^{11}$}

Bitlis Kalesi, Doğu Anadolu Bölgesi’nde bulunan Bitlis ilinin merkezinde yer almaktadır. Kalenin batısındaki İskender ile doğusundaki Dideban Çayı kayalık bir tepe üzerinde bulunan kalenin etrafında doğal bir hendek oluşturmuştur. Bitlis Kalesi'nin ne zaman ve kimler tarafindan yaptırıldığ 1 kesin olarak bilinmemekle birlikte bölge Hz. Ömer döneminde fethedilene kadar farklı medeniyetlere ev sahipliği yapmış; Emevi ve Abbasi devletlerinin hâkimiyetinden sonra 10. yüzyılda Bizans ile Mervani devletleri arasında sınır şehri olmuştur. ${ }^{12}$ Büyük Selçuklu Sultanı Melikşah tarafından 1084 yılında fethedilen şehir, Dilmaçoğlu Mehmet Bey’e bırakılmış ${ }^{13}, 1192$ yılında Ahlat Atabeyleri, 1207 yılında Eyyubiler ${ }^{14}$ bölgeyi egemenliği altına almıştır. 1230 yılında Anadolu Selçukluları daha sonra ise Karakoyunlu, Akkoyunlu, Safeviler ve son olarak 1514 yılında Yavuz Sultan Selim'in Çaldıran seferi dönüşünde Osmanlı Devleti bölgeye hâkim olmuştur. ${ }^{15}$

2018 yılı Bitlis Kalesi kazısı, kalenin güney surları ile daha önceki kazı dönemlerinde ortaya çıkarılan hamam yapısı arasındaki kalan P ve R 14-15 plan karesi içerisinde, kazılacak alanla bağlantılı olarak 6x5 m ölçülerindeki iki açmada yapıllmıştır (G. 1) (G. 3). 6x5 m açılan iki açma mimari kalıntılarla bağlantılı olarak aradaki kesitlerin kaldırılmasıyla genişletilmiştir (G 2). Açmalar içerisinde açılan sondajdan ele geçirilen veriler ise Bitlis Kale kazısının stratigrafik açıdan anlaşılmasına yardımcı olmaktadır. Yan yana iki mekânda yapılan kazı çalışmaları sırasında lüle dışında çok sayıda seramik, sikke, metal obje, cam ve günlük yaşama dair buluntular ele geçirilmiştir. Lüle buluntularının bir kısmıyla birlikte birçok kahve fincanı da bulunmuştur.

10 BOA, MVL, 954-58 (H. 1278/M.1861)

112018 yılı kazı çalışmaları (MK 011301 Proje Numaralı) Ahlat Müze Müdürlüğü denetiminde, Bakanlık temsilcisi Uzman Arkeolog Azat Örmek'in katılımıyla ve Dr. Öğr. Üyesi Korkmaz Şen’in bilimsel danışmanl1ğında yapılmıştır. 2004-2015 Bitlis Kale kazısı hakkında bilgi için bkz. Kadir Pektaş, "Bitlis Kale Kazısı 2006 Y1lı Çalışmaları", 29. Kazı Sonuçları Toplantısı (28 Mayıs-1 Haziran 2007) 1 (Kocaeli: Kültür ve Turizm Bakanlığı1, 2008), 245-262; Kadir Pektaş, "Bitlis Kale Kazısı 2007 Yılı Çalışmaları”, 30. Kazı Sonuçları Toplantısı (26-30 Mayıs 2008) 4 (Ankara: Kültür ve Turizm Bakanlığı, 2009), 317-326; Kadir Pektaş, "Bitlis Kale Kazısı 2008”, 31. Kazı Sonuçları Toplantısı (25-29 Mayıs 2009) 4 (Denizli: Kültür ve Turizm Bakanlığg1, 2010), 85-100; Kadir Pektaş, "Bitlis Kalesi 2009 Yılı Kazısı", 32. Kazı Sonuçları Toplantısı (24-28 Mayıs 2010) 4 (İstanbul: Kültür ve Turizm Bakanlığı, 2011), 285-298; Gülsen Baş, Bitlis Kalesi Arkeolojik Kazı Çalışmaları (2011-2015), (İstanbul: Ege Yayınları, 2018).

12 Metin Tuncel, "Bitlis”, TDV Íslam Ansiklopedisi, c. 6 (İstanbul: Türkiye Diyanet Vakfı Yayınları, 1992), 226.

13 Osman Turan, Doğu Anadolu Türk Devletleri Tarihi (İstanbul: Ötüken, 2001), 111.

14 M. Oluş Arık, Bitlis Yapılarında Selçuklu Rönesansı (Ankara: Selçuklu Tarih ve Medeniyet Enstitüsü, 1971), 7.

15 Tuncel, "Bitlis", 226-227. 


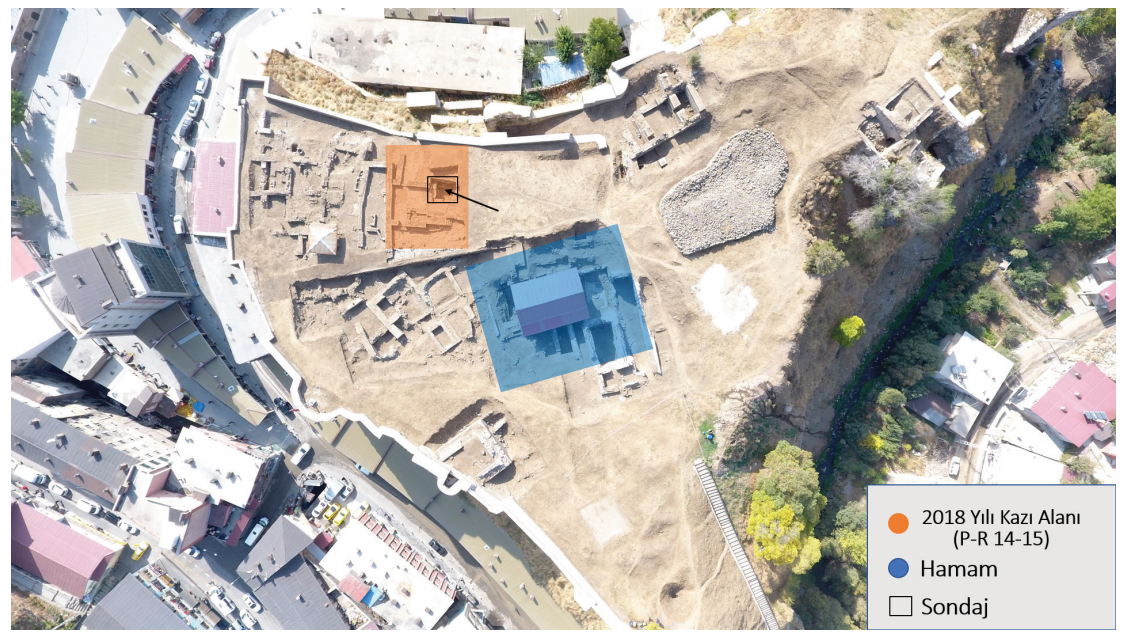

G. 1. Bitlis Kalesi Kazı Alanı (Korkmaz Şen, Yunus Emre Karasu, 2018)

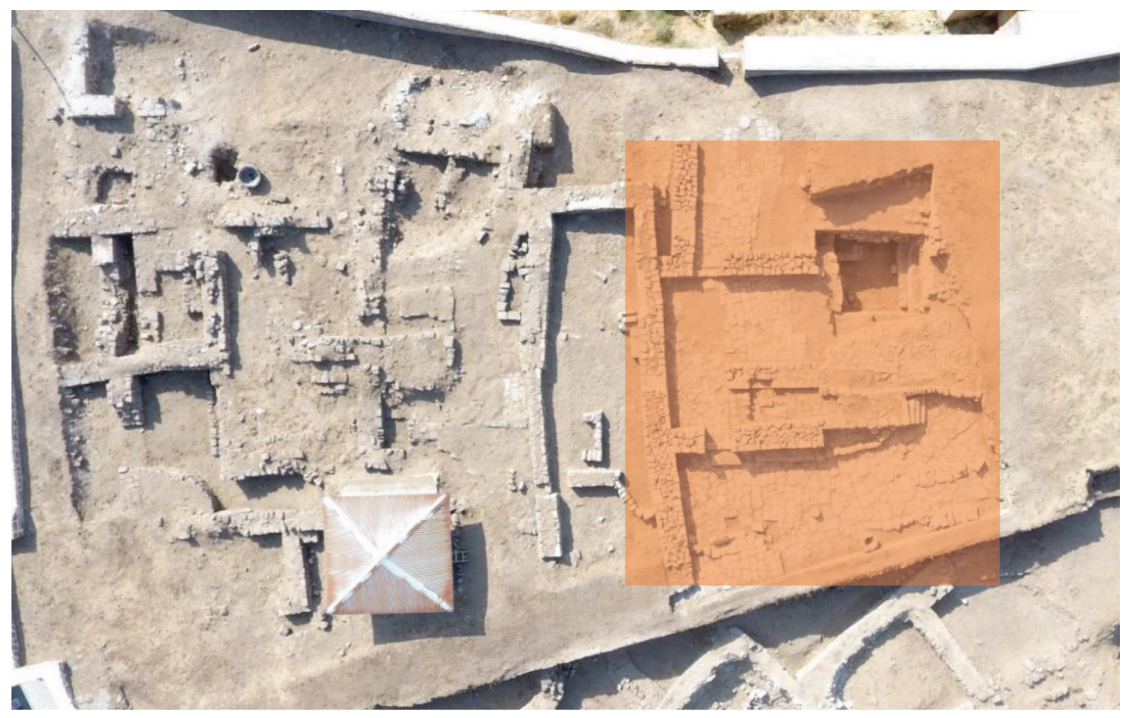

G. 2. Bitlis Kalesi P-R 14-15 Numaralı Açmalar ve Sondaj Alanı (Korkmaz Şen, Yunus Emre Karasu, 2018) 


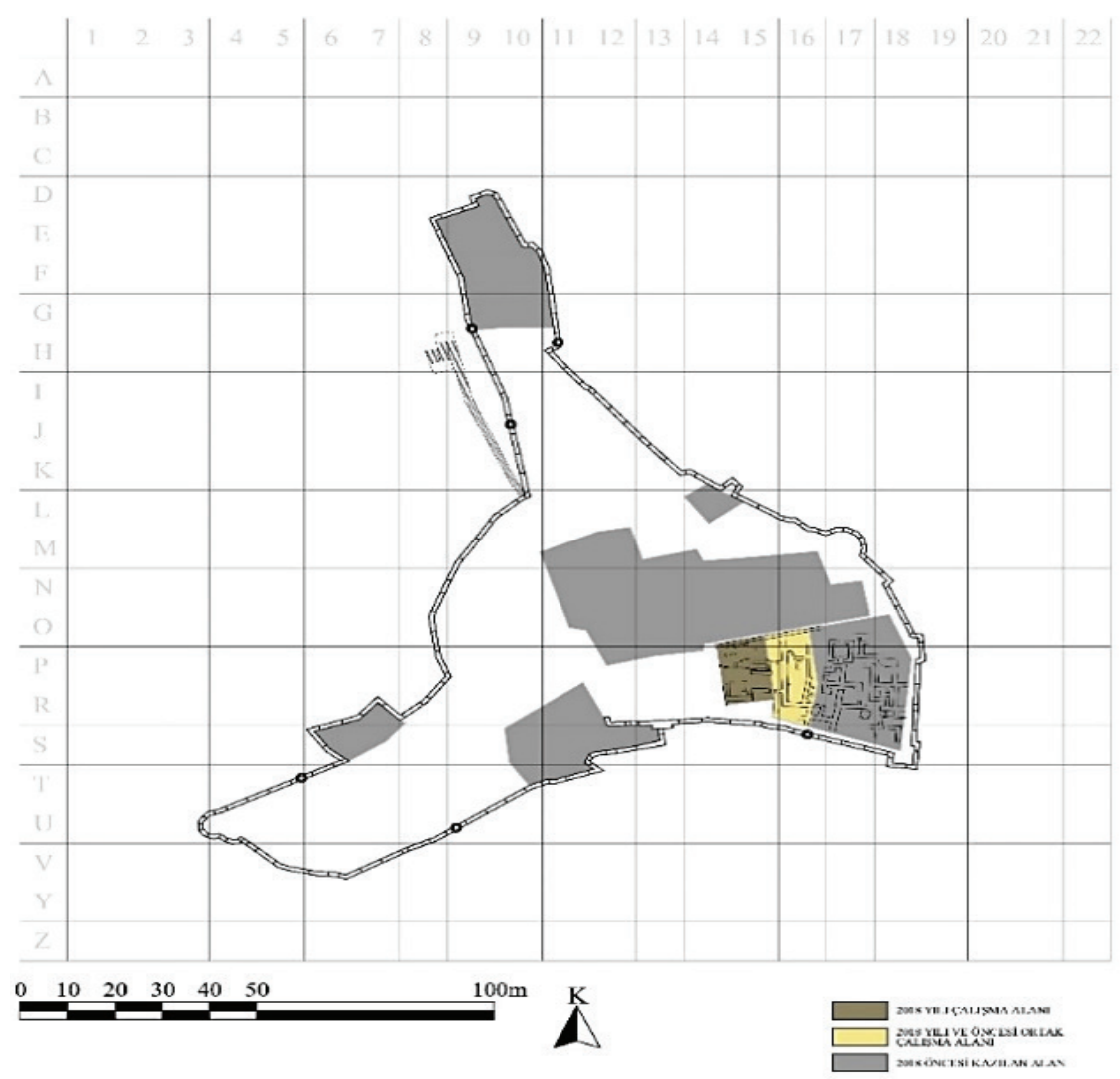

G. 3. 2018 Y1lı Bitlis Kale Kazısı Plan Kare Haritası (Bitlis Kazı Arşivi, 2018)

\section{Yılı Bitlis Kale Kazısı Lüle Buluntuları ${ }^{16}$}

2018 yılı Bitlis Kale kazısında form veren lüleler içerisinde süzgeçli ve süzgeçsiz basık yuvarlak çanaklı lüleler en yoğun görülen form gruplarını oluşturmaktadır. Bu gruplar dışında disk kaideli, yuvarlak çanaklı, karinalı çanaklı, lale çanaklı, torba biçimli çanaklı ve silindir çanaklı forma sahip lüle örnekleri ve çok sayıda sadece duman yolu mevcut lüle buluntuları ele geçirilmiştir (T. 1) (T. 2). Lüle tipolojisiyle ilgili birçok çalışma bulunmaktadır. Ancak bu çalışmada Bakla ve Robinson'un genel kabul görmüş form tipolojisi kullanılmıştır. ${ }^{17}$ Farklı formlara sahip lüle buluntuları genellikle temiz hamurlu, az ve küçük boyutlu katkılı olup, az gözenekli ve iyi pişmiş durumdadır. Hamur içerisinde ise mika, kireç, kum ve şamot gibi katkı maddeleri görülmektedir (T. 3).

162018 yılı Bitlis Kale kazısında ele geçirilen diğer lüleler için bkz. Şen ve Karasu, "2018 Yı1ı Bitlis Kale Kazısı Kaideli, Süzgeçli Çanaklı Lüle Buluntuları", 189-206.

17 Erdinç Bakla, Tophane Lüleciliği (İstanbul: Dışbank Yayınları, 1993); Rebecca Robinson "Clay Tobacco Pipes From the Kerameikos", Mitteilüngen 98 (1983), 265-285. 
Tablo 1

2018 Y11ı Bitlis Kale Kazısı Lüle Buluntuları (Korkmaz Şen, Yunus Emre Karasu, 2018)

\begin{tabular}{|l|c|}
\hline Bitlis Kale Kazısı Lüle Formları: & Adet \\
\hline 1. Süzgeçli, Basık Yuvarlak Çanaklı Lüleler: & 24 \\
\hline 2. Disk Kaideli Lüleler: & 5 \\
\hline 3. Lale (Zambak) Çanaklı Lüleler: & 3 \\
\hline 4. Yuvarlak Çanaklı Lüleler: & 8 \\
\hline 5. Silindir Çanaklı Lüleler: & 4 \\
\hline 6. Karinalı Çanaklı Lüleler: & 7 \\
\hline 7. Torba Biçimli Çanaklı Lüleler: & 10 \\
\hline 8. Basık Yuvarlak Çanaklı Lüleler (Süzgeçsiz): & 20 \\
\hline 9. Basık Yuvarlak Kaideli Süzgeçli Lüleler: & 1 \\
\hline Toplam: & 82 \\
\hline
\end{tabular}

Tablo 2

2018 Y11ı Bitlis Kale Kazısı Lüle Dağılımı (Korkmaz Şen, Yunus Emre Karasu, 2018)

\section{Yılı Bitlis Kale Kazısı Lüle Buluntuları}

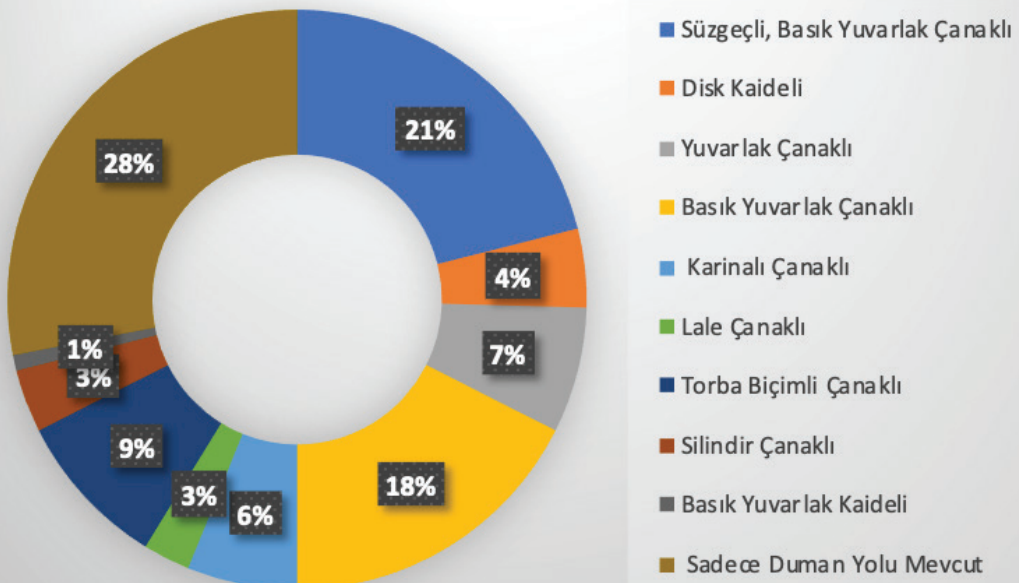


Tablo 3

Lüle Buluntularının Özellikleri (Korkmaz Şen, Yunus Emre Karasu, 2018)

\begin{tabular}{|c|c|c|c|c|}
\hline No & \multicolumn{2}{|c|}{ Hamur Rengi } & Katkı & Adet \\
\hline 1. & 2.5 Y $5 / 1$ & Gri & Mika, Kireç, Kum & 1 \\
\hline 2. & Koyu Gri & Koyu Gri & Kireç, Kum, Şamot & 2 \\
\hline 3. & 2.5 YR 5/6 & Kırmızı & Mika, Kireç, Kum & 2 \\
\hline 4. & 2.5 YR $5 / 6$ & Kirmız1 & Mika, Kum & 1 \\
\hline 5. & 2.5 YR $6 / 6$ & Açık Kırmızı & Mika, Kireç, Kum & 1 \\
\hline 6. & $2.5 \mathrm{YR} 7 / 6$ & Açık Kırmızı & Mika, Kireç, Kum & 1 \\
\hline 7. & $2.5 \mathrm{YR} 8 / 4$ & Pembe & Mika, Kireç, Kum & 1 \\
\hline 8. & $5 \mathrm{YR} 8 / 4$ & Pembe & Mika, Kireç, Kum, Şamot & 1 \\
\hline 9. & $5 \mathrm{YR} 7 / 6$ & Kırmızıms1 sar1 & Kireç, Kum & 1 \\
\hline 10. & $7.5 \mathrm{YR} 8 / 1$ & Beyaz & Mika, Kum & 2 \\
\hline 11. & 7.5 YR $8 / 4$ & Pembe & Mika, Kireç, Şamot & 1 \\
\hline 12. & $10 \mathrm{YR} 8 / 1$ & Beyaz & Mika, Kireç, Kum & 12 \\
\hline 13. & $10 \mathrm{YR} 8 / 2$ & Açık Kahverengi & Kireç, Kum & 1 \\
\hline 14. & $10 \mathrm{YR} 8 / 2$ & Açık Kahverengi & Mika, Kireç & 1 \\
\hline 15. & $10 \mathrm{YR} 8 / 2$ & Açık Kahverengi & Mika, Kum & 2 \\
\hline 16. & $10 \mathrm{YR} 8 / 2$ & Açık Kahverengi & Kireç, Kum, Şamot & 3 \\
\hline 17. & $10 \mathrm{YR} 8 / 2$ & Açık Kahverengi & Mika, Kireç, Kum & 18 \\
\hline 18. & $10 \mathrm{YR} 8 / 2$ & Açık Kahverengi & Mika, Kum, Şamot & 2 \\
\hline 19. & $10 \mathrm{YR} 8 / 2$ & Açık Kahverengi & Mika, Kireç, Kum, Şamot & 1 \\
\hline 20. & $10 \mathrm{YR}_{-} 1 / 9.5$ & Beyaz & Mika, Kireç, Kum & 3 \\
\hline 21. & N.9 & Beyaz & Mika, Kum, Şamot & 1 \\
\hline Top & & & & 59 \\
\hline
\end{tabular}

1. Süzgeçli, Basık Yuvarlak Çanaklı Lüleler: Çanak kısmı süzgeçli ve basık yuvarlak yarım daire çanaklı lüle buluntuları bu grubu oluşturmaktadır (T. 4), (G. 4). 2018 yılı Bitlis kale kazısında 24 adet süzgeçli, basık yuvarlak çanaklı lüle ele geçirilmiştir. Buluntular içerisinde 22 lüle siyah renkli diş yüzeye sahip, koyu gri hamurlu ve perdahlı olup 2 lüle yüzeyi açık kahverengi hamurlu ve mat şekildedir. İki parçadan oluşan kalıpla yapılan süzgeçli, basık yuvarlak çanaklı lüleler az, küçük boyutlu katkılı ve temiz hamurlu olup hamurları koyu gri renklidir. Dış yüzeyi siyah renkli olan lülelerin fırınlama sırasında siyah renge dönüştürüldüğü ve fırınlama öncesinde hamurlarının kahverengi tonlarda olduğu düşünülmektedir. Dış yüzeyinde yer yer açık gri renk izler bulunan bir süzgeçli, basık yuvarlak çanaklı lüle örneği ise açık kahverengi hamurlu, astarsız ve perdahlıdır (G. 4/S-2). Ele geçirilen süzgeçli, basık yuvarlak çanaklı lülelerden onunda oyma ve rulet baskı; ikisinde oyma; üçünde oyma, rulet ve baskı bezeme görülmekte olup dokuzu bezemesizdir. Bu grup lülelerin 
benzer örnekleri Cizre Kalesi'nde 19. yüzyıl sonu-20. yüzyıl başına ${ }^{18}$, Hasankeyf'te 19. yüzyıla ${ }^{19}$, Siirt Başur Höyük'te 19. yüzy1la ${ }^{20}$ tarihlendirilmekle birlikte Van Hoşap Kale kazısında $^{21}$, Gevale Kale kazısında ${ }^{22}$, Alaşehir Kurşunlu Han kazısında ${ }^{23}$, Eski Van şehri kazılarında ${ }^{24}$ da görülmektedir. Bitlis Kale kazısında yüzeye yakın şekilde ele geçirilen bu grup lülelerin bölgede yerleşimin görüldüğü son dönemlere ait olduğu düşünülmektedir. Kazı çalışmalarında ele geçirilen diğer buluntular ve benzer örnekleri göz önüne alındığında süzgeçli, basık çanaklı lüleler 19. yüzyıla tarihlendirilmiştir. Yerel üretim olduğunu düşündüğümüz bu gruptaki lüleler süzgeçlidir. Tütünün oldukça önemli ve çok talep edilen bir ürün olması sonucu lüleler içerisine süzgeç konularak lüleye yerleştirilen tütünün hepsinin tüketilebilmesine olanak sağlanmıştır. Ayrıca ekonomik etkenler dışında kullanılan tütünün türüne göre de lülelerde süzgecin kullanıldığı düşünülebilir.

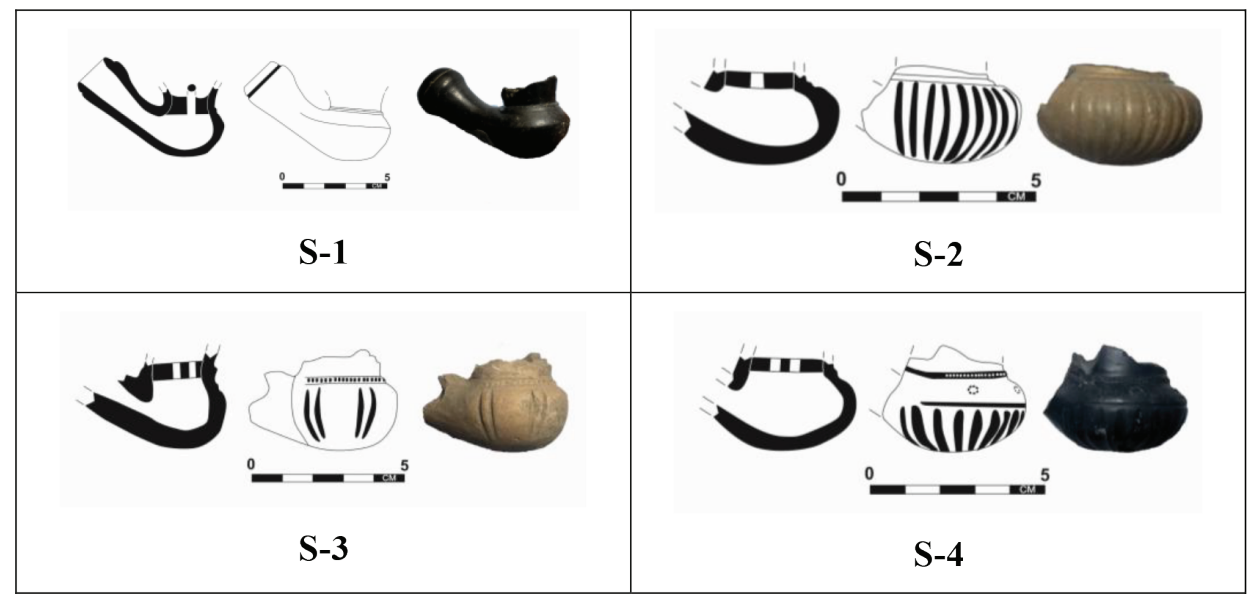

G. 4. Süzgeçli, Basık Yuvarlak Çanaklı Lüleler (Korkmaz Şen, Yunus Emre Karasu, 2018)

18 Gizem Saldırgan, “Cizre İç Kale Kazısı Lüle Buluntuları”, I. Uluslararası Sosyal Bilimler Kongresi (31 Ocak-2 Şubat 2018) (Kayseri: Erciyes Üniversitesi Yayınları, 2018), 611.

19 Gökben Ayhan, "Hasankeyf Kazısı Lüle Buluntuları” (Doktora Tezi, Ege Üniversitesi, 2011), 268-273; Gökben Ayhan, "Hasankeyf Kazısı Lüle Buluntularının Değerlendirilmesi”, Ege Üniversitesi Edebiyat Fakültesi Sanat Tarihi Dergisi XIX/1 (2010), 18.

20 Gökben Ayhan, "Başur Höyük Kazısı Lüle Buluntuları”, XIII. Ortaçağ ve Türk Dönemi Kazılarl ve Sanat Tarihi Araştırmaları Sempozyumu Bildirileri (14-16 Ekim 2009) (Denizli: Pamukkale Üniversitesi, 2010), 53.

21 Mehmet Top, “Hoşap Kalesi Kazısı 2007”, IV. Uluslararası Van Gölü Havzası Sempozyumu (17-21 Haziran 2008) (Bitlis: Bitlis Eren Üniversitesi, 2011), 116.

22 Ahmet Çaycı ve Zekeriya Şimşir, “Gevale Kalesi 2015 Yılı Arkeolojik Kazı Çalışmaları”, XX. Uluslararası Ortaçağ ve Türk Dönemi Kazıları ve Sanat Tarihi Araştırmaları Sempozyumu Bildirileri (02-05 Kasım 2016), c. 1 (Sakarya: Sakarya Üniversitesi, 2017), 46.

23 Ertan Daş, “Alaşehir Kurşunlu Han Kazı ve Temizlik Çalışmaları”, XIII. Ortaçağ ve Türk Dönemi Kazıları ve Sanat Tarihi Araştırmaları Sempozyumu Bildirileri (14-16 Ekim 2009) (Denizli: Ege Yayınları, 2010), 211.

24 H. Banu Konyar, Ahmet Vefa Çobanoğlu ve Ayşe Denknalbant Çobanoğlu, "Eski Van Şehri, Kalesi ve Höyüğü Kazıları Eski Van Şehri Alanı 2013 Yı1ı Çalışmaları”, Uluslararası XVIII. Ortaçağ ve Türk Dönemi Kazıları ve Sanat Tarihi Araştırmaları Sempozyumu Bildirileri (22-25 Ekim 2014) (Aydın: Efeler Belediyesi Kültür Yayınları, 2017), 386. 
Tablo 4

Süzgeçli, Basık Yuvarlak Çanaklı Lülelerin Özellikleri (Korkmaz Şen, Yunus Emre Karasu, 2018)

\begin{tabular}{|c|c|c|c|c|c|c|}
\hline No & $\begin{array}{c}\text { Hamur } \\
\text { Rengi }\end{array}$ & Katkı & $\begin{array}{c}\text { Duman Yolu } \\
\text { Ağız Çapı }\end{array}$ & $\begin{array}{c}\text { Duman Yolu } \\
\text { Uzunluğu }\end{array}$ & Yükseklik & Bezeme \\
\hline S-1 & Koyu Gri & $\begin{array}{c}\text { Kireç, Kum, } \\
\text { Şamot }\end{array}$ & $1,6 \mathrm{~cm}$ & $4,3 \mathrm{~cm}$ & $4,6 \mathrm{~cm}$ & Kalıp \\
\hline S-2 & 10 YR 8/2 & $\begin{array}{c}\text { Kireç, Kum, } \\
\text { Şamot }\end{array}$ & - & - & $2,4 \mathrm{~cm}$ & Kazıma \\
\hline S-3 & 10 YR 8/1 & $\begin{array}{c}\text { Mika, Kireç, } \\
\text { Kum }\end{array}$ & - & $1,4 \mathrm{~cm}$ & $3,3 \mathrm{~cm}$ & $\begin{array}{c}\text { Kazıma, } \\
\text { Rulet }\end{array}$ \\
\hline S-4 & Koyu Gri & $\begin{array}{c}\text { Kireç, Kum, } \\
\text { Şamot }\end{array}$ & - & - & $3 \mathrm{~cm}$ & $\begin{array}{c}\text { Bask1, Rulet, } \\
\text { Kazıma }\end{array}$ \\
\hline
\end{tabular}

2. Disk Kaideli Lüleler: Yayınlarda genellikle disk kaideli olarak geçen bu formdaki lüleler, çalışmamızda aynı şekilde isimlendirilmiştir. Bitlis Kale'sinde ele geçirilen disk şeklindeki çanakların alt kısmında herhangi bir çıkıntı olmadığı ve düz şekilde devam ettikleri görülmektedir. 2018 yılı Bitlis Kale kazısında 5 adet disk kaideli lüle buluntusu ele geçirilmiştir (T. 5) (G .5). Az-küçük katkıl1, temiz hamurlu, sık gözenekli bir hamur yapısına sahip olan lülelerden dördü kırmızı astarlı ve perdahlı, biri ise beyaz astarlı ve perdahsızdır. Ele geçirilen disk kaideli lülelerden birinde kazıma, üçünde baskı, birinde rulet ve baskı bezeme görülür. Bu grup lüle buluntularının benzerleri Cizre İç Kale kazısında 19. yüzyıla25, Hasankeyf kazısında 19. yüzyıla ${ }^{26}$, Akşehir Taş Medrese Müzesi’nde 19. yüzyılaa ${ }^{27}$, Antalya Kaleiçi kazısında 18. yüzyıl-20. yüzyıl başlarına ${ }^{28}$, Bursa Tophane kazısında 18. yüzyıl sonu19. yüzyıla ${ }^{29}$, Demirköy Fatih Dökümhanesi Kazısında 19. yüzyıla ${ }^{30}$, Smyrna Antik Kenti kazısında 19. yüzyıla ${ }^{31}$, Komana Antik Kenti kazısında 19. yüzyıl-20. yüzyılın başına $^{32}$ tarihlendirilmiştir. Ayrıca Bilecik Osmanlı dönemi çarşı alanı kazısında ${ }^{33}$ ve

25 Saldırgan, "Cizre İç Kale Kazısı Lüle Buluntuları", 612-613.

26 Ayhan, "Hasankeyf Kazısı Lüle Buluntuları", 303.

27 Sevinç Gök Gürhan. “Akşehir Taş Medrese Müzesi’ndeki Türk Dönemi Seramikleri (2000-2001 Anıt Meydan'da Yapılan Kurtarma Kazısı Seramikleri)", (Doktora Tezi, Ege Üniversitesi, 2007), 258.

28 Azize Yener, "Tütün Lüleleri ve Antalya-Kaleiçi’nde Bulunan Örnekler”, Arkeoloji ve Sanat 119 (2005), 102-107.

29 Filiz İnanan ve Derya Şahin, “Arkeopark-Osmanlı Lüleleri Osmanlı’da Tütün Keyfi”, Uludağ Üniversitesi Fen-Edebiyat Fakültesi Sosyal Bilimler Dergisi 18/32 (2017), 42-43.

30 Ali Osman Uysal, "Demirköy Fatih Dökümhanesi Kazısı Seramik Buluntuları", Byzas 7, Çanak: Akdeniz Çevresindeki Arkeolojik Kazılarda Ele Geçen Antik ve Ortaçağ Seramiği ve Mimari Seramiği (İstanbul: Ege Yayınları, 2007), 555-557; Nurcan Yazıcı Metin, "Demirköy Fatih Dökümhanesi Kazısı Lüle Buluntuları (2010-2015)", Sanat Tarihi Ylllı̆̆ 28 (2019), 92.

31 Gökben Ayhan, "Smyrna Antik Kenti Kazıları 2007-2008 Yı1ı Lüle Buluntuları”, Ege Üniversitesi Edebiyat Fakültesi Sanat Tarihi Dergisi XVIII/2 (2009), 15.

32 Gökben Ayhan, "An Evaluation on Tobacco Pipes Usage in the Tokat Region: In the Light of Tobacco Pipe Findings of Komana Excavation", Komana Small Finds, ed. D. Burcu Erciyas ve Meryem Acara Eser (İstanbul: Ege Yayınları, 2019), 376.

33 Erol Altınsapan, "2002 Yılı Bilecik Osmanlı Dönemi Çarşı Alanı Kazısı”, 25. Kazı Sonuçları Toplantısı 2 (Ankara: Kültür ve Turizm Bakanlığı, 2004), 264. 
Hoşap kalesinde ${ }^{34}$ de benzer formda lüleler bulunmuştur. Hamur, katk1, bezeme, form açısından incelenen lüleler benzer örnekleri de göz önüne alındığında 19. yüzyıla tarihlendirilmektedir.

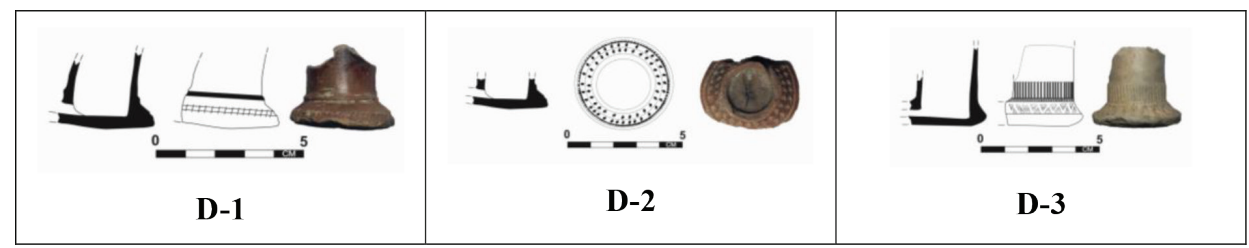

G. 5. Disk Kaideli Lüleler (Korkmaz Şen, Yunus Emre Karasu, 2018)

Tablo 5

Disk Kaideli Lülelerin Özellikleri (Korkmaz Şen, Yunus Emre Karasu, 2018)

\begin{tabular}{|c|c|c|c|c|c|c|}
\hline No & $\begin{array}{c}\text { Hamur } \\
\text { Rengi }\end{array}$ & Katkı & $\begin{array}{c}\text { Çanak } \\
\text { Çapı }\end{array}$ & Yükseklik & Bezeme & Astar \\
\hline D-1 & 10 YR 8/3 & Mika, Kireç, Kum & $3,2 \mathrm{~cm}$ & $2,6 \mathrm{~cm}$ & Kazıma & Kırmızı \\
\hline D-2 & 10 YR $8 / 1$ & Mika, Kum, Şamot & $3,2 \mathrm{~cm}$ & $1,3 \mathrm{~cm}$ & Bask1 & Kırmızı \\
\hline D-3 & 10 YR $8 / 2$ & Mika, Kum, Şamot & $2,6 \mathrm{~cm}$ & $3,4 \mathrm{~cm}$ & Baskı, Rulet & Beyaz \\
\hline
\end{tabular}

3. Lale (Zambak) Çanaklı Lüleler: Zambak şeklinde çanak kısmından ağız kısmına doğru genişleyen ya da lale benzeri çanak ve ağız formuna sahip olan lülelerdir. 2018 yılı Bitlis Kale kazısında lale çanaklı 3 adet lüle buluntusu ele geçirilmiştir (T. 6) (G. 6). Bu gruptaki lüleler az, küçük boyutlu, katkı1ı temiz bir hamur yapısına sahip olmakla birlikte büyük çanaklıdır. Ele geçirilen lüle örneklerinden ikisi kırmızı astarlı, perdahlı baskılı ve rulet baskıl1; bir lüle ise astarsız, perdahsız ve kazıma bezemelidir. Kırmızı astarlı her iki lüle örneğinin çanak kısmında baskı tekniğiyle yapılmış mask benzeri süslemeler yer almaktadır. Ayrıca 2018 yılı kazı çalışmaları sırasında ele geçirilen bir lale çanaklı lüle üzerinde yer alan mühürde "uzun sıhhat" yazmaktadır. (G. 6/L-1) Bu grup lülelerin benzer örnekleri Cizre İç Kale kazısında 19. yüzyıla ${ }^{35}$, Hasankeyf'te 19. yüzyıla ${ }^{36}$, Antalya Kaleiçi'nde 19. yüzy1la ${ }^{37}$, Harput 19-20. yüzy1$1 a^{38}$, Akşehir Taş Medrese Müzesi 19. yüzyıl sonuna ${ }^{39}$, Smyrna Antik Kenti Kazısında 19. yüzy1l sonu-20. yüzyıl başına ${ }^{40}$, Edirne Yeni Saray kazısında 19. yüzyılaa ${ }^{41}$, Aziz

34 Mehmet Top ve Oktay Başak, "Hoşap Kalesi Kazısı 2011”, XVI. Ortaçağ-Türk Dönemi Kazıları ve Sanat Tarihi Araștrmaları Seтроzyumu Bildirileri (18-20 Ekim 2012), c. 2 (Sivas: Cumhuriyet Üniversitesi, 2014), 763.

35 Saldırgan, "Cizre İç Kale Kazısı Lüle Buluntuları", 613-614.

36 Ayhan, "Hasankeyf Kazısı Lüle Buluntuları", 293-296.

37 Yener, “Tütün Lüleleri ve Antalya-Kaleiçi’nde Bulunan Örnekler", 107- 110.

38 İsmail Aytaç, "Harput İç Kale Kazılarında 2015-2016 Yıllarında Bulunan Tütün Lülelerinin Değerlendirilmesi”, Yaşar Erdemir'e Armağan: Sanat Tarihi Yazılarl (Konya: LiteraTürk Academia, 2019), 591-593; Veli Sevin, Necla Arslan Sevin ve Haydar Kalsen, Harput Kale Mahallesinde Osmanlı Yaşamı (İstanbul: Ege Yayınları, 2011), 185.

39 Gök Gürhan, “Akşehir Taş Medrese Müzesi'ndeki Türk Dönemi Seramikleri (2000-2001 Anıt Meydan'da Yapılan Kurtarma Kazısı Seramikleri)”, 267.

40 Ayhan, "Smyrna Antik Kenti Kazıları 2007-2008 Yılı Lüle Buluntuları", 13.

41 Aysun Cengiz, "Edirne Yeni Saray Kazılarında Ele Geçen Lüleler” (Yüksek Lisans Tezi, Gazi Üniversitesi, 2011), 187. 
Nikolaos Kilisesi Kazısında 19. yüzyıl-20. yüzyıl başına ${ }^{42}$, Kemah Kale kazısında 18-19. yüzyıla ${ }^{43}$ tarihlendirilmektedir. Yüzeye yakın şekilde ve genellikle süzgeçli basık yuvarlak çanaklı lülelerle birlikte ele geçirilen bu grup örnekler 19. yüzyıla tarihlendirilmektedir.

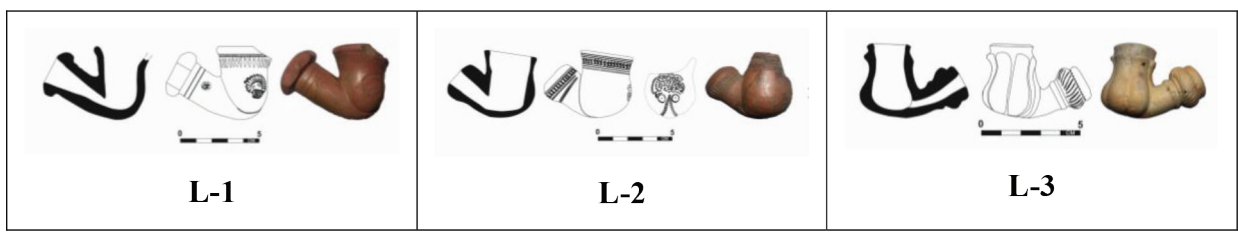

G. 6. Lale Çanaklı Lüleler (Korkmaz Şen, Yunus Emre Karasu 2018)

Tablo 6

Lale Çanaklı Lülelerin Özellikleri (Korkmaz Şen, Yunus Emre Karasu, 2018)

\begin{tabular}{|c|c|c|c|c|c|c|c|c|}
\hline No & $\begin{array}{c}\text { Hamur } \\
\text { Rengi }\end{array}$ & Katkı & $\begin{array}{c}\text { Ağız } \\
\text { Çapı }\end{array}$ & $\begin{array}{c}\text { Duman Yolu } \\
\text { Ağız Çapı }\end{array}$ & $\begin{array}{c}\text { Duman Yolu } \\
\text { Uzunluğu }\end{array}$ & Yükseklik & Bezeme & Astar \\
\hline L-1 & 2.5 YR 7/6 & $\begin{array}{c}\text { Mika, } \\
\text { Kireç, Kum }\end{array}$ & $3,6 \mathrm{~cm}$ & $1,8 \mathrm{~cm}$ & $3,8 \mathrm{~cm}$ & $4,6 \mathrm{~cm}$ & $\begin{array}{c}\text { Bask1, } \\
\text { Rulet }\end{array}$ & Kırmız1 \\
\hline L-2 & 2.5 YR 6/6 & $\begin{array}{c}\text { Mika, } \\
\text { Kireç, Kum }\end{array}$ & $3 \mathrm{~cm}$ & $1 \mathrm{~cm}$ & $2,6 \mathrm{~cm}$ & $4,3 \mathrm{~cm}$ & $\begin{array}{c}\text { Bask1, } \\
\text { Rulet }\end{array}$ & Kırmız1 \\
\hline L-3 & 10 YR 8/2 & $\begin{array}{c}\text { Mika, } \\
\text { Kireç, Kum }\end{array}$ & $1,8 \mathrm{~cm}$ & $0,8 \mathrm{~cm}$ & $2,8 \mathrm{~cm}$ & $3,6 \mathrm{~cm}$ & Kazıma & - \\
\hline
\end{tabular}

4. Yuvarlak Çanaklı Lüleler: Çanak kısmı yarım yuvarlak formda olan lüleler bu grubu oluşturmaktadır. 2018 yılı Bitlis Kale kazısında sekiz adet yuvarlak çanaklı lüle buluntusu ele geçirilmiş olup bu lülelerden ikisi kahverengi astarl1-perdahlı, üçü kırmızı astarl1-perdahlı, dördü astarsız ve perdahsızdır (T. 7) (G. 7). Küçük boyutlu az katkılı olan lülelerden üçünde kalıp, ikisinde kalıp ve baskı, birinde kalıp ve rulet bask1, ikisinde baskı ve rulet bezeme görülmektedir. Bu grubun benzer örnekleri Hasankeyf kazısında 18. yüzyıla ${ }^{44}$, Tire Kutu Han'da 18-19. yüzyıla ${ }^{45}$, Kudüs'te 18-19. yüzyıla ${ }^{46}$ tarihlendirilmektedir. Benzer örnekleri ve diğer kazı buluntuları göz ününe alındığında yuvarlak çanaklı lüleler 18. yüzyıl ortası-19. yüzyıla tarihlendirilmektedir.

42 Ebru Fatma Fındık, “Ay Işığında Tütün Seremonisi-Osmanlı Kırsalında Tütün Kullanımının Kanıtları: Aziz Nikolaos Kilisesi Kazıları Lüle ve Nargile Buluntuları”, Cedrus: The Journal of Mcri IV (2016), 377-379.

43 Hüseyin Yurttaş, Haldun Özkan, Zerrin Köşklü, Süleyman Çiğdem, Nurşen Özkul Fındık ve Muhammet L. Kındığılı, "Kemah Kale Kazısı 2014 Yı1ı Çalışmaları", Uluslararası XIX. Ortaçă̆ ve Türk Dönemi Kazıları ve Sanat Tarihi Araştırmaları Sempozyumu (21-24 Ekim 2015), c. II, Yay. Haz. Ceren Ünal ve Cengiz Gürbiyık (Ankara: Türk Tarih Kurumu, 2019), 636.

44 Ayhan, "Hasankeyf Kazısı Lüle Buluntuları", 231.

45 Hasan Uçar, "Archaeological Proof of Enjoy at Tire Kutu Han: Clay Pipes”, Mediterranean Archaeology and Archaeometry 19 (2) (2019), 123.

46 John Simpson, "Late Ottoman Pipes From Jerusalem”, Excavations by K. M. Kenyon In Jerusalem 19611967, vol. V (Oxford: Oxbow Books, 2008), 433-443. 


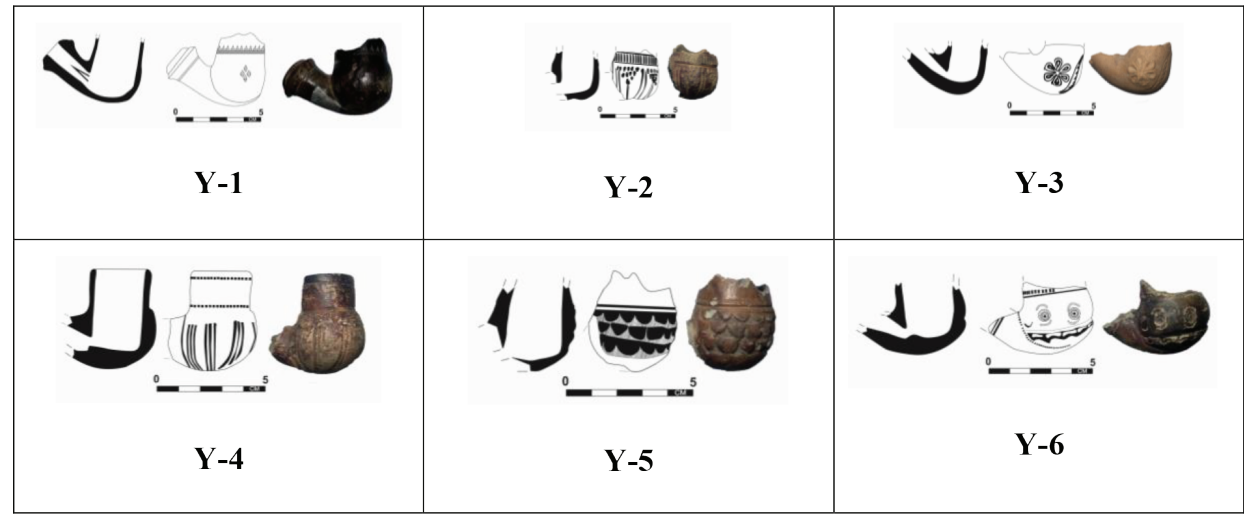

G. 7. Yuvarlak Çanaklı Lüleler (Korkmaz Şen, Yunus Emre Karasu, 2018)

Tablo 7

Yuvarlak Çanaklı Lülelerin Özellikleri (Korkmaz Şen, Yunus Emre Karasu, 2018)

\begin{tabular}{|c|c|c|c|c|c|c|c|c|}
\hline No & $\begin{array}{c}\text { Hamur } \\
\text { Rengi }\end{array}$ & Katkı & $\begin{array}{c}\text { Ağız } \\
\text { Çapı }\end{array}$ & $\begin{array}{c}\text { Duman Yolu } \\
\text { Ăğı Çapı }\end{array}$ & $\begin{array}{c}\text { Duman Yolu } \\
\text { Uzunluğu }\end{array}$ & Yükseklik & Bezeme & Astar \\
\hline Y-1 & 10 YR 8/2 & Mika, Kireç & - & $1,1 \mathrm{~cm}$ & $2,5 \mathrm{~cm}$ & $3,8 \mathrm{~cm}$ & $\begin{array}{c}\text { Bask1, } \\
\text { Rulet }\end{array}$ & Kahve \\
\hline Y-2 & 10 YR 8/2 & $\begin{array}{c}\text { Mika, Kireç, } \\
\text { Kum }\end{array}$ & - & - & - & $3,4 \mathrm{~cm}$ & $\begin{array}{c}\text { Bask1, } \\
\text { Kazıma }\end{array}$ & - \\
\hline Y-3 & 5 YR 7/6 & Kireç, Kum & - & - & $2,4 \mathrm{~cm}$ & $2,9 \mathrm{~cm}$ & Kalıp & - \\
\hline Y-4 & $\begin{array}{c}2.5 \text { YR } \\
8 / 4\end{array}$ & $\begin{array}{c}\text { Mika, Kireç, } \\
\text { Kum }\end{array}$ & $2,6 \mathrm{~cm}$ & - & - & $4,6 \mathrm{~cm}$ & $\begin{array}{c}\text { Kazıma, } \\
\text { Bask1 }\end{array}$ & Kırmızı \\
\hline Y-5 & $\begin{array}{c}10 \text { YR 8/2 } \\
\text { Mika, Kireç, } \\
\text { Kum }\end{array}$ & - & - & - & $3,8 \mathrm{~cm}$ & Kalıp & Kırmızı \\
\hline Y-6 & 10 YR 8/1 & Kireç, Kum & - & - & $2 \mathrm{~cm}$ & $3,7 \mathrm{~cm}$ & Bask1 & Kahve \\
\hline
\end{tabular}

5. Silindir Çanaklı Lüleler: Çanak alt kısmı yuvarlak veya basık yuvarlak formlu olup ağız kenarına kadar silindir şeklinde uzanan lülelerdir. 2018 yılı Bitlis Kale kazısında üç adet silindir çanaklı lüle buluntusu ele geçirilmiştir. (T. 8) (G. 8) Silindir çanaklı lülelerden ikisi astarsız ve perdahsız olup biri kırmızı astarlı ve perdahlıdır. Silindir çanaklı benzer lüle örnekleri Siirt Başur Höyük kazısında 17. yüzyıl-18. yüzyıl başına ${ }^{47}$, Komana Antik Kenti kazısında 18. yüzyılın başına ${ }^{48}$ tarihlendirilmektedir. Ancak Bitlis Kale kazısında ele geçirilen bu grup lüleler kazı çalışmalarında elde edilen veriler sonucunda 18. yüzyıl ortası-19. yüzyıla tarihlendirilmiştir.

47 Ayhan, "Başur Höyük Kazısı Lüle Buluntuları”, 53.

48 Ayhan, "An Evaluation on Tobacco Pipes Usage in the Tokat Region: In the Light of Tobacco Pipe Findings of Komana Excavation”, 362. 


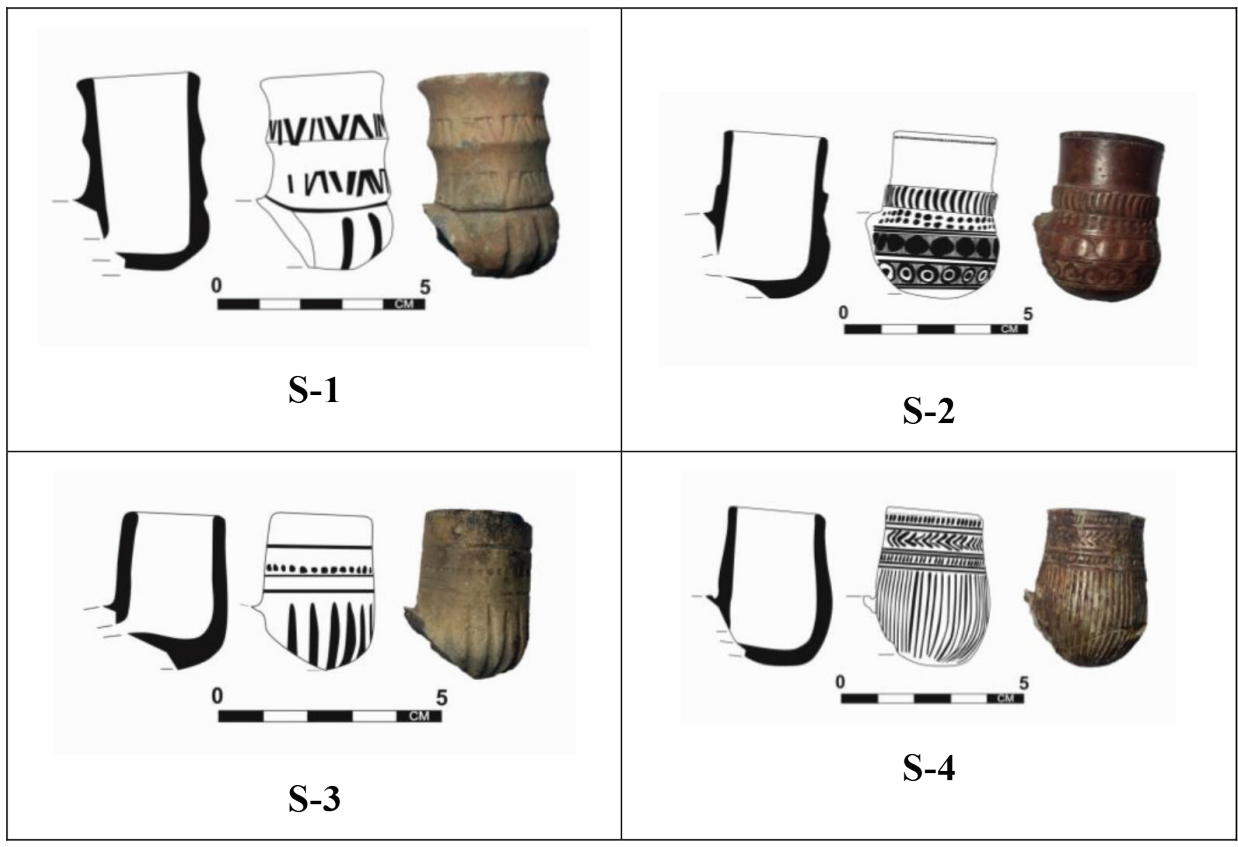

G. 8. Silindir Çanaklı Lüleler (Korkmaz Şen, Yunus Emre Karasu, 2018)

Tablo 8

Silindir Çanaklı Lülelerin Özellikleri (Korkmaz Şen, Yunus Emre Karasu, 2018)

\begin{tabular}{|c|c|c|c|c|c|c|c|}
\hline No & $\begin{array}{c}\text { Hamur } \\
\text { Rengi }\end{array}$ & Katkı & $\begin{array}{c}\text { Ağız } \\
\text { Çapı }\end{array}$ & $\begin{array}{c}\text { Duman Yolu } \\
\text { Ağız Çapı }\end{array}$ & Yükseklik & Bezeme & Astar \\
\hline S-1 & 10 YR 8/1 & $\begin{array}{c}\text { Mika, Kireç, } \\
\text { Kum }\end{array}$ & $2,4 \mathrm{~cm}$ & - & $5 \mathrm{~cm}$ & Bask1 & - \\
\hline S-2 & 10 YR 8/1 & $\begin{array}{c}\text { Mika, Kireç, } \\
\text { Kum }\end{array}$ & $2,6 \mathrm{~cm}$ & - & $4,5 \mathrm{~cm}$ & Bakı, Rulet & Kırmızı \\
\hline S-3 & 10 YR 8/2 & $\begin{array}{c}\text { Mika, Kireç, } \\
\text { Kum }\end{array}$ & $2 \mathrm{~cm}$ & - & $3,5 \mathrm{~cm}$ & $\begin{array}{c}\text { Kazıma, } \\
\text { Rulet }\end{array}$ & - \\
\hline S-4 & 10 YR 8/1 & Kireç, Kum & $2,2 \mathrm{~cm}$ & - & $4,2 \mathrm{~cm}$ & $\begin{array}{c}\text { Kazıma, } \\
\text { Rulet }\end{array}$ & Kırmızı \\
\hline
\end{tabular}

6. Karinalı Çanaklı Lüleler: Gemi omurgası anlamına gelen karinalı lülelerin çanak kısmı, gemi omurgası şeklinde çıkıntılı ve keskin dönüşlü bir form özelliği göstermektedir. Bu lüleler genellikle çanak kısmında meydana gelen keskin kırılma altında kalan düz kısım üzerine oturmaktadır. 2018 yılı Bitlis Kale kazısında 7 adet karinalı çanaklı lüle buluntusu ele geçirilmiştir (T. 9) (G. 9). Bulunan karinalı çanaklı lüleler kaba bir hamur yapısına sahip olup genellikle bezemesiz ve oldukça küçük boyutlardadır. Sadece bir lüle örneği sık dokulu, temiz hamurlu, kırmızı astarlı olup perdahsız ve mat bir görünüme sahiptir (G. 9/K-5). G. 9'da gösterilen K-4 ve K-5 numaralı lülelerin çanak kısmında yoğun bezeme olduğu için çanak kısmındaki kırılma 
diğer karinalı çanaklı lülelerdeki kadar keskin değildir. Ele geçirilen 7 adet karinalı çanaklı lülelerden biri baskı, ikisi oyma ve baskı bezemeli olup dördü bezemesizdir. Bu grup lülelerin benzer örnekleri Cizre İç Kale'sinde 17-18. yüzy1la ${ }^{49}$, Hasankeyf'te 17-18. yüzy1la ${ }^{50}$, Komana Antik Kenti'nde 17-18. yüzyıla ${ }^{51}$, Antalya Kaleiçi'nde 18. yüzyıla ${ }^{52}$ tarihlendirilmiştir. Kazı çalışmalarından elde edilen bilgiler ve benzer örnekleri göz önüne alındığında bu grup lüleler 18. yüzyıla tarihlendirilmiştir.

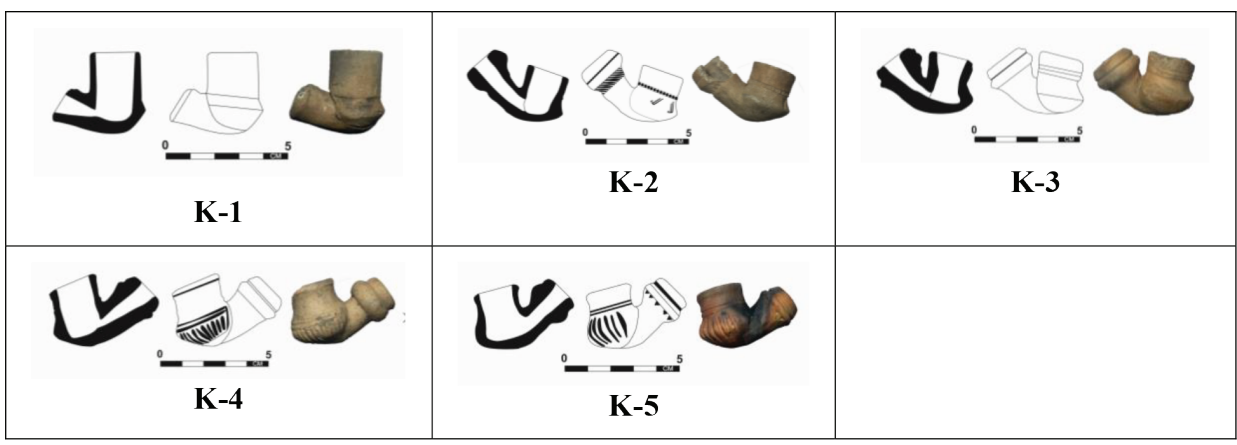

G. 9. Karinalı Çanaklı Lüleler (Korkmaz Şen, Yunus Emre Karasu, 2018)

Tablo 9

Karinalı Çanaklı Lülelerin Özellikleri (Korkmaz Şen, Yunus Emre Karasu, 2018)

\begin{tabular}{|l|c|c|c|c|c|c|c|c|}
\hline No & $\begin{array}{c}\text { Hamur } \\
\text { Rengi }\end{array}$ & Katkı & $\begin{array}{c}\text { Ăğız } \\
\text { Çapı }\end{array}$ & $\begin{array}{c}\text { Duman Yolu } \\
\text { Ağız Çapı }\end{array}$ & $\begin{array}{c}\text { Duman Yolu } \\
\text { Uzunluğu }\end{array}$ & Yükseklik & Bezeme & Astar \\
\hline K-1 & 10 YR 8/2 & $\begin{array}{c}\text { Mika, } \\
\text { Kireç, Kum }\end{array}$ & $\begin{array}{c}1,8 \\
\mathrm{~cm}\end{array}$ & $0,9 \mathrm{~cm}$ & $1,4 \mathrm{~cm}$ & $3,4 \mathrm{~cm}$ & Kalıp & - \\
\hline K-2 & 10 YR 8/1 & $\begin{array}{c}\text { Mika, } \\
\text { Kireç, Kum }\end{array}$ & $2 \mathrm{~cm}$ & $1 \mathrm{~cm}$ & $3,2 \mathrm{~cm}$ & $2,7 \mathrm{~cm}$ & Bask1 & - \\
\hline K-3 & 5 YR 8/4 & $\begin{array}{c}\text { Mika, } \\
\text { Kireç, Kum, } \\
\text { Şamot }\end{array}$ & $\begin{array}{c}1,8 \\
\mathrm{~cm}\end{array}$ & $1,2 \mathrm{~cm}$ & $2,5 \mathrm{~cm}$ & $2,9 \mathrm{~cm}$ & Kalıp & - \\
\hline K-4 & 10 YR 8/2 & $\begin{array}{c}\text { Mika, } \\
\text { Kireç, Kum }\end{array}$ & $\begin{array}{c}1,6 \\
\mathrm{~cm}\end{array}$ & $1,5 \mathrm{~cm}$ & $3,1 \mathrm{~cm}$ & $3 \mathrm{~cm}$ & $\begin{array}{c}\text { Kalıp, } \\
\text { Kazıma }\end{array}$ & - \\
\hline K-5 & 7.5 YR \\
$8 / 4$ & $\begin{array}{c}\text { Mika, } \\
\text { Kireç, } \\
\text { Şamot }\end{array}$ & $\begin{array}{c}1,4 \\
\mathrm{~cm}\end{array}$ & $0,7 \mathrm{~cm}$ & $2,1 \mathrm{~cm}$ & $2,8 \mathrm{~cm}$ & $\begin{array}{c}\text { Kazıma, } \\
\text { Kalıp, } \\
\text { Bask1 }\end{array}$ & Kırmızı \\
\hline
\end{tabular}

7. Torba Biçimli Çanaklı Lüleler: Çanak alt kısmı farklı biçimlerde şişkin ve yayvan olup ağız kısmına doğru daralan lülelerdir. Ancak bu form özelliğini gösteren lüleler için kullanılan "torba biçimli çanaklı lüle" terminolojisinde tam olarak bir anlam

49 Saldırgan, "Cizre İç Kale Kazısı Lüle Buluntuları”, 613.

50 Ayhan, "Hasankeyf Kazısı Lüle Buluntuları”, 162-225..

51 D. Burcu Erciyas ve Mustafa N. Tatbul, “Anadolu'da Ortaçağ Kazıları ve Komana”, 37. Kazı Sonuçları Toplantısı (11-15 Mayıs 2015, Erzurum), c. 2 (Ankara: Kültür ve Turizm Bakanlığı, 2016), 623; Ayhan, “An Evaluation on Tobacco Pipes Usage in the Tokat Region: İn the Light of Tobacco Pipe Findings of Komana Excavation", 356-357.

52 Yener, “Tütün Lüleleri ve Antalya-Kaleiçi’nde Bulunan Örnekler”, 97-98 (Çiz. II, 8). 
bütünlüğü sağlanamıştır ve yer yer karmaşaya sebep olabilmektedir. 2018 yılı Bitlis Kale kazısında 10 adet torba biçimli çanaklı lüle ele geçirilmiş olup beşinde baskı, ikisinde oyma ve üçünde kazıma bezeme görülmektedir. (T.10) (G.10) Bu grup lülelerin benzer örnekleri Cizre İç Kale kazısında 18. yüzyıla ${ }^{53}$, Hasankeyf'te 18. yüzyıla ${ }^{54}$ tarihlendirilmiştir. Benzer örnekleri ve diğer kazı buluntuları göz önüne alındığında torba biçimli çanaklı lüleler 18. yüzyıla tarihlendirilmektedir. Sadece bir örnek (G. 10/T-2) diğer örneklerden daha derinde bulunmuş olup 17-18. yüzyıla tarihlendirilmektedir.

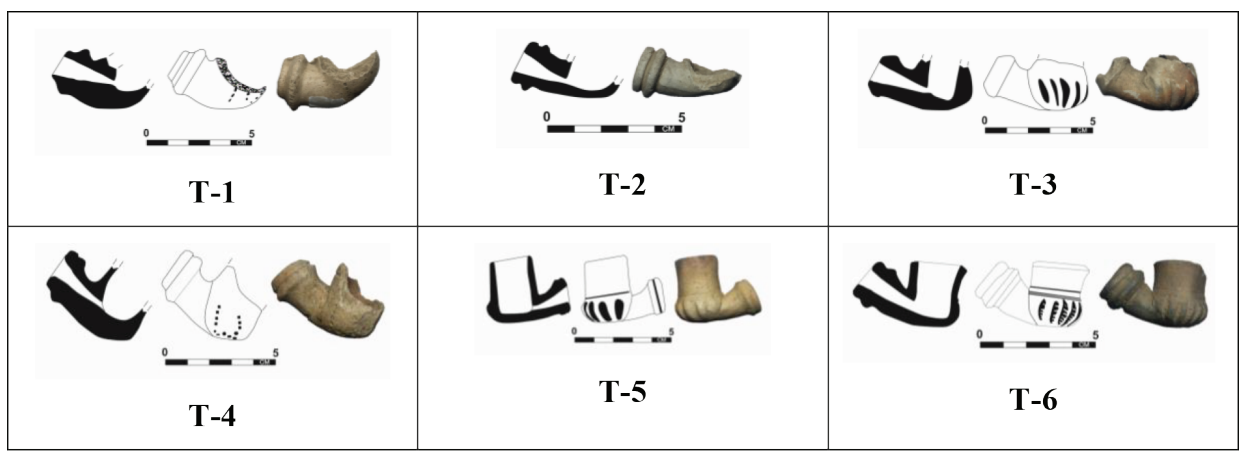

G. 10. Torba Biçimli Çanaklı Lüleler (Korkmaz Şen, Yunus Emre Karasu, 2018)

Tablo 10

Torba Biçimli Çanaklı Lülelerin Özellikleri (Korkmaz Şen, Yunus Emre Karasu, 2018)

\begin{tabular}{|l|c|c|c|c|c|c|c|c|}
\hline No & $\begin{array}{c}\text { Hamur } \\
\text { Rengi }\end{array}$ & Katkı & $\begin{array}{c}\text { Ăğı } \\
\text { Çapı }\end{array}$ & $\begin{array}{c}\text { Duman Yolu } \\
\text { Ağız Çapı }\end{array}$ & $\begin{array}{c}\text { Duman Yolu } \\
\text { Uzunluğu }\end{array}$ & Yükseklik & Bezeme & Astar \\
\hline T-1 & 10 YR 8/2 & $\begin{array}{c}\text { Kireç, Kum, } \\
\text { Şamot }\end{array}$ & - & $1,1 \mathrm{~cm}$ & $2,1 \mathrm{~cm}$ & $2,7 \mathrm{~cm}$ & Kalıp & \\
\hline T-2 & 10 YR 8/2 & $\begin{array}{c}\text { Kireç, Kum, } \\
\text { Şamot }\end{array}$ & - & $0,9 \mathrm{~cm}$ & $1,9 \mathrm{~cm}$ & $1,5 \mathrm{~cm}$ & Bask1 & \\
\hline T-3 & 10 YR 8/2 & Kireç, Kum & - & $0,9 \mathrm{~cm}$ & $2,6 \mathrm{~cm}$ & $2,3 \mathrm{~cm}$ & Kazıma & \\
\hline T-4 & 10 YR 8/2 & $\begin{array}{c}\text { Mika, } \\
\text { Kireç, Kum }\end{array}$ & - & $1,4 \mathrm{~cm}$ & $2,8 \mathrm{~cm}$ & $3,2 \mathrm{~cm}$ & Bask1 & \\
\hline T-5 & 10 YR 8/2 & $\begin{array}{c}\text { Mika, } \\
\text { Kireç, Kum }\end{array}$ & $\begin{array}{c}1,8 \\
\mathrm{~cm}\end{array}$ & $1 \mathrm{~cm}$ & $1,8 \mathrm{~cm}$ & $3,4 \mathrm{~cm}$ & Kazıma & \\
\hline T-6 & 10 YR 8/2 & Mika, Kum & $\begin{array}{c}1,8 \\
\mathrm{~cm}\end{array}$ & $1,1 \mathrm{~cm}$ & $2,4 \mathrm{~cm}$ & $2,7 \mathrm{~cm}$ & Bask1 & - \\
\hline
\end{tabular}

8. Basık Yuvarlak Çanaklı Lüleler (Süzgeçsiz): Yarım yuvarlak çanak kısmı bir noktadan basık olan lülelerdir. Genellikle çanağın uç kısmı basık şekilde olup lüle kullanılırken basık kısım yere gelmektedir. 2018 yılı Bitlis Kale kazısında en yoğun şekilde ele geçirilen bu grup lülelerinden biri kahverengi astarl1-perdahlı, üçü kırmızı astarl1-perdahlı, ikisi kırmızı astarl1-perdahsız, biri beyaz astarl1-perdahlı olup on üçü

53 Saldırgan, “Cizre İç Kale Kazısı Lüle Buluntuları”, 614.

54 Ayhan, "Hasankeyf Kazısı Lüle Buluntuları”, 151-154, 157-161. 
astarsız ve perdahsızdır (T. 11) (G. 11). Lüle buluntularından yedisinde oyma, üçünde oyma ve bask1, altısında kalıp, dördünde baskı bezeme görülmektedir. $\mathrm{Bu}$ grup lülelerin benzer örnekleri Hasankeyf'te 17-18. yüzy1la ${ }^{55}$ tarihlendirilmektedir. Benzer örnekler ve kazı çalışmaları sırasında elde edilen veriler dikkate alındığında basık yuvarlak çanaklı lüleler 17-18. yüzyıla tarihlendirilmektedir. Özellikle G. 11'de yer alan B-7 ve B-10 numaralı lüleler kazı alanında sondaj çalışmalarının sürdürüldüğü daha derin kısımda bulunduğundan 17. yüzyıla ait oldukları düşünülmektedir.

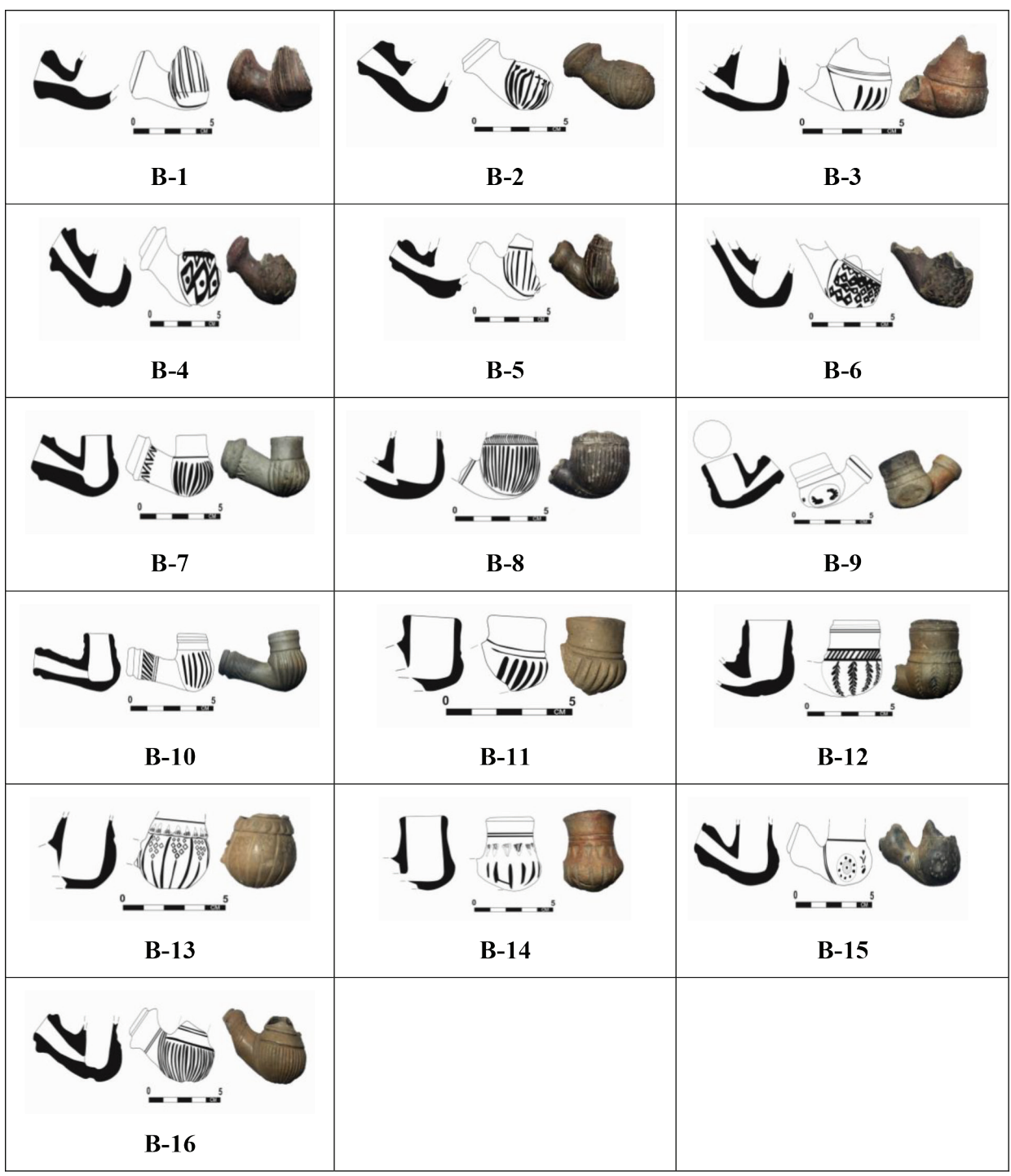

G. 11. Basık Yuvarlak Çanaklı Lüleler (Süzgeçsiz) (Korkmaz Şen, Yunus Emre Karasu, 2018) 
Tablo 11.

Basık Yuvarlak Çanaklı Lülelerin Özellikleri (Süzgeçsiz) (Korkmaz Şen, Yunus Emre Karasu, 2018)

\begin{tabular}{|c|c|c|c|c|c|c|c|c|}
\hline No & $\begin{array}{l}\text { Hamur } \\
\text { Rengi }\end{array}$ & Katkı & $\begin{array}{l}\text { Ăğı } \\
\text { Çapı }\end{array}$ & $\begin{array}{c}\text { Duman Yolu } \\
\text { Ağız Çapı }\end{array}$ & $\begin{array}{c}\text { Duman Yolu } \\
\text { Uzunluğu }\end{array}$ & Yükseklik & Bezeme & Astar \\
\hline B-1 & $10 \mathrm{YR} 8 / 2$ & $\begin{array}{c}\text { Mika, } \\
\text { Kireç, Kum } \\
\end{array}$ & - & $1 \mathrm{~cm}$ & $2,3 \mathrm{~cm}$ & $2,8 \mathrm{~cm}$ & Kazıma & Kahve \\
\hline B-2 & $\begin{array}{l}2.5 \text { YR } 5 / 6 \\
7.5 \text { YR } 6 / 4\end{array}$ & $\begin{array}{c}\text { Mika, } \\
\text { Kireç, Kum }\end{array}$ & - & $1,1 \mathrm{~cm}$ & $2,3 \mathrm{~cm}$ & $3,8 \mathrm{~cm}$ & Bask1 & - \\
\hline B-3 & $10 \mathrm{YR} 8 / 2$ & $\begin{array}{c}\text { Mika, } \\
\text { Kireç, Kum, } \\
\text { Şamot } \\
\end{array}$ & - & - & $1,4 \mathrm{~cm}$ & $4 \mathrm{~cm}$ & Kazıma & Kırmız1 \\
\hline B-4 & $\begin{array}{r}10 \mathrm{YR} \\
1 / 9.5 \\
\end{array}$ & $\begin{array}{c}\text { Mika, } \\
\text { Kireç, Kum }\end{array}$ & - & $1,1 \mathrm{~cm}$ & $3 \mathrm{~cm}$ & $2,5 \mathrm{~cm}$ & Kalıp & Kırmız1 \\
\hline B-5 & $\begin{array}{r}10 \mathrm{YR} \\
1 / 9.5\end{array}$ & $\begin{array}{c}\text { Mika, } \\
\text { Kireç, Kum }\end{array}$ & - & $1 \mathrm{~cm}$ & $3,8 \mathrm{~cm}$ & $3,5 \mathrm{~cm}$ & $\begin{array}{c}\text { Kazıma, } \\
\text { Bask1 }\end{array}$ & Kırmız1 \\
\hline B-6 & $10 \mathrm{YR} 8 / 2$ & $\begin{array}{c}\text { Mika, } \\
\text { Kireç, Kum }\end{array}$ & - & - & $2,8 \mathrm{~cm}$ & $3,4 \mathrm{~cm}$ & Kalıp & Kırmız1 \\
\hline B-7 & N.9 & $\begin{array}{l}\text { Mika, Kum, } \\
\text { Şamot }\end{array}$ & $1,6 \mathrm{~cm}$ & $1 \mathrm{~cm}$ & $2,8 \mathrm{~cm}$ & $2,9 \mathrm{~cm}$ & $\begin{array}{l}\text { Kalıp, } \\
\text { Kazıma }\end{array}$ & Beyaz \\
\hline B-8 & $10 \mathrm{YR} 8 / 1$ & $\begin{array}{c}\text { Mika, Kum, } \\
\text { Şamot }\end{array}$ & - & - & $1,5 \mathrm{~cm}$ & $3,2 \mathrm{~cm}$ & Kalıp & Kırmız1 \\
\hline B-9 & $10 \mathrm{YR} 8 / 1$ & $\begin{array}{c}\text { Mika, } \\
\text { Kireç, Kum }\end{array}$ & $1,8 \mathrm{~cm}$ & $1 \mathrm{~cm}$ & $2,3 \mathrm{~cm}$ & $3,4 \mathrm{~cm}$ & Bask1 & - \\
\hline B-10 & 10 YR $8 / 1$ & $\begin{array}{l}\text { Kireç, } \\
\text { Kum, } \\
\text { Şamot }\end{array}$ & $1,5 \mathrm{~cm}$ & $1 \mathrm{~cm}$ & $3,4 \mathrm{~cm}$ & $3 \mathrm{~cm}$ & $\begin{array}{l}\text { Kalıp, } \\
\text { Rulet }\end{array}$ & Beyaz \\
\hline B-11 & $10 \mathrm{YR} 8 / 2$ & $\begin{array}{c}\text { Mika, } \\
\text { Kireç, Kum }\end{array}$ & $1,8 \mathrm{~cm}$ & - & - & $2,9 \mathrm{~cm}$ & Kazıma & - \\
\hline B-12 & $\begin{array}{r}10 \mathrm{YR} \\
1 / 9.5\end{array}$ & $\begin{array}{c}\text { Mika, } \\
\text { Kireç, Kum }\end{array}$ & $2,6 \mathrm{~cm}$ & - & - & $4,6 \mathrm{~cm}$ & Bask1 & - \\
\hline B-13 & $10 \mathrm{YR} 8 / 2$ & $\begin{array}{c}\text { Mika, } \\
\text { Kireç, Kum }\end{array}$ & - & - & - & $3,9 \mathrm{~cm}$ & $\begin{array}{c}\text { Kazıma, } \\
\text { Bask1 }\end{array}$ & Beyaz \\
\hline B-14 & $10 \mathrm{YR} 8 / 2$ & $\begin{array}{c}\text { Mika, } \\
\text { Kireç, Kum }\end{array}$ & $2,4 \mathrm{~cm}$ & - & & $4,7 \mathrm{~cm}$ & Bask1 & Kırmız1 \\
\hline B-15 & $10 \mathrm{YR} 8 / 2$ & $\begin{array}{c}\text { Mika, } \\
\text { Kireç, Kum } \\
\end{array}$ & - & $0,9 \mathrm{~cm}$ & $2,8 \mathrm{~cm}$ & $2,9 \mathrm{~cm}$ & Bask1 & Beyaz \\
\hline B-16 & $10 \mathrm{YR} 8 / 1$ & $\begin{array}{c}\text { Mika, } \\
\text { Kireç, Kum }\end{array}$ & & $1,2 \mathrm{~cm}$ & $3,5 \mathrm{~cm}$ & $3 \mathrm{~cm}$ & Kazıma & - \\
\hline
\end{tabular}

9. Basık Yuvarlak Kaideli Süzgeçli Lüleler: Çanak ve kaidesi bitişik olup kaide kısmı çanak kısmına doğru yarım yuvarlak daire şeklinde basık olan lülelerdir. 2018 yılı Bitlis Kale kazısında bu form özelliğine sahip sadece 1 adet lüle ele geçirilmiştir. (G. 12) Oldukça iyi pişmiş olan lüle üzerinde yer yer yanık izleri mevcuttur. Çanak kısmı üzerinde ise dikey şekilde tek sıra rulet baskı bezeme şeritler yer almaktadır. ( $\mathrm{T}$. 12) Lülenin form yönünden benzer örneği Ayasuluk İç Kale kazısında görülmektedir. ${ }^{56}$ Kazı çalışmaları sırasında elde edilen veriler doğrultusunda başka bölgelerde benzer örneği görülmeyen bu grup lüleler, 18. yüzyıl sonu-19. yüzyıla tarihlendirilmiştir.

56 Gökben Ayhan, "Ayasuluk İç Kalesi “Süzgeç Çanaklı” ve "Kaideli Süzgeç Çanaklı” Lüle Buluntuları”, Mustafa Büyükkolancı'ya Armağan, ed. Celal Şimşek-Bahadır Duman-Erim Konakçı (İstanbul: Ege Yayınları, 2015), 41-53. 


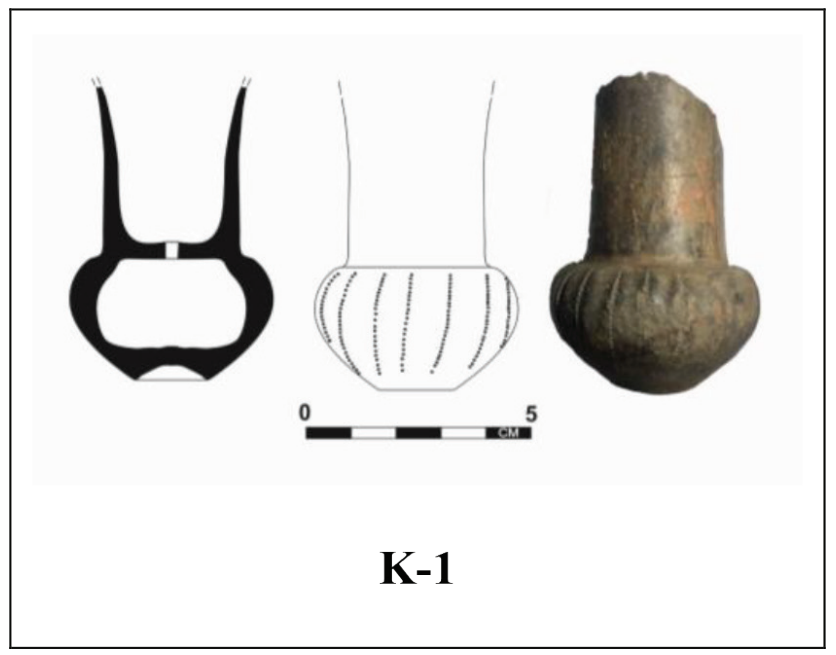

G. 12. Basık Yuvarlak Kaideli Süzgeçli Lüleler (Korkmaz Şen, Yunus Emre Karasu, 2018)

Tablo 12

Basık Yuvarlak Kaideli Süzgeçli Lüle Özellikleri (Korkmaz Şen, Yunus Emre Karasu, 2018)

\begin{tabular}{|c|c|c|c|c|c|c|c|}
\hline No & $\begin{array}{c}\text { Hamur } \\
\text { Rengi }\end{array}$ & Katkı & $\begin{array}{c}\text { ĂğIZ } \\
\text { Çapı }\end{array}$ & Dip Çapı & $\begin{array}{c}\text { Duman Yolu } \\
\text { Ağız Çapı }\end{array}$ & Yükseklik & Bezeme \\
\hline K-1 & 10 YR 8/2 & $\begin{array}{c}\text { Mika, Kireç, } \\
\text { Kum }\end{array}$ & - & $1,6 \mathrm{~cm}$ & $1 \mathrm{~cm}$ & $6,7 \mathrm{~cm}$ & Rulet \\
\hline
\end{tabular}

\section{Değerlendirme}

Formlarına göre başlıklara ayrılan Bitlis Kalesi lüle buluntularının benzer örnekleri Anadolu'nun farklı bölgelerinde yaygın olarak görülmektedir. Formu belli olan lüleler dışında sadece duman yolu mevcut olan örnekler ile bir köz kabı (?) da kazı çalışmasında ele geçirilen buluntular arasındadır. Bu buluntular çalışmamızın form bütünlüğü açısından değerlendirme kısmında ele alınmıştır.

Sadece Duman Yolu Mevcut Lüleler: Kırık şekilde ele geçirilen bu grupta yer alan lüleler genellikle ya duman yolu ile çanağın birleştiği kısımdan ya da çanağın duman yoluyla birleştiği kısımdan hemen sonra kırılmış olup form özellikleri tam olarak anlaşılamamaktadır. Sadece duman yolu mevcut otuz iki lüleden altısında rulet, on ikisinde kalıp, üçünde kalıp ve rulet, dördünde kazıma ve rulet, ikisinde rulet ve bask1, dördünde baskı, birinde kalıp ve baskı bezeme yer almaktadır (T. 13) (G. 13).

G. 13'te yer alan D-1, 2, 3, 6, 7, 8, 10, 11 numaralı örnekler kirli beyaz tonda, az katk1lı ve temiz hamurlu olup oldukça kaliteli bir bezemeye sahiptir. Benzer örnekleri Hasankeyf'te 17-18. yüzyıla ${ }^{57}$, Ramla' da 18. yüzyıl başlarına ${ }^{58}$; D-4, 5, 9, 
12 numaralı örnekler Hasankeyf'te 18-19. yüzyıla ${ }^{59}$ tarihlendirilmiştir. Kazı çalışmaları sırasında elde edilen veriler ışığında D-1, 2, 3, 6, 7, 8, 10, 11 numaralı duman yolları 17-18. yüzyıla; D-4, 5, 9, 12 numaralı duman yolları ise 19. Yüzyıla, netice olarak oldukça farklı boyut ve bezeme özelliklerine sahip olan lüle duman yolları, benzer örnekleri göz önüne alındığında 17-19. yüzyıl arasında farklı yüzyıllara tarihlendirilmektedir.

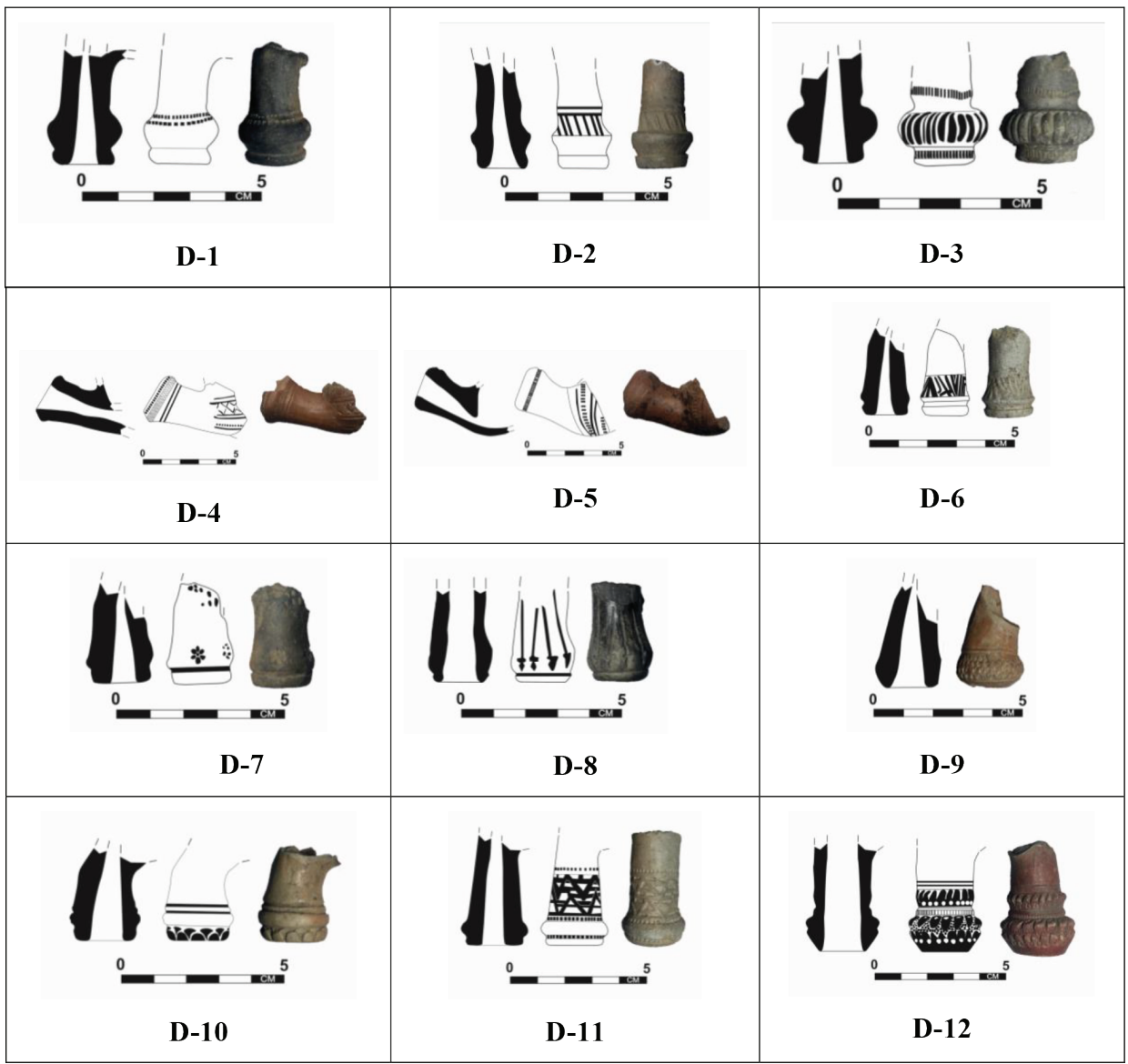

G. 13. Sadece Duman Yolu Mevcut Lüleler (Korkmaz Şen, Yunus Emre Karasu, 2018) 
Tablo 13

Sadece Duman Yolu Mevcut Lülelerin Özellikleri (Korkmaz Şen, Yunus Emre Karasu, 2018)

\begin{tabular}{|c|c|c|c|c|c|c|c|}
\hline No & $\begin{array}{c}\text { Hamur } \\
\text { Rengi }\end{array}$ & Katkı & $\begin{array}{c}\text { Duman Yolu } \\
\text { Ağız Çapı }\end{array}$ & $\begin{array}{c}\text { Duman Yolu } \\
\text { Uzunluğu }\end{array}$ & Yükseklik & Bezeme & Astar \\
\hline D-1 & 10 YR $8 / 2$ & $\begin{array}{c}\text { Mika, } \\
\text { Kireç, Kum }\end{array}$ & $0,9 \mathrm{~cm}$ & $3,5 \mathrm{~cm}$ & $2,1 \mathrm{~cm}$ & Rulet & - \\
\hline D-2 & 7.5 YR 8/1 & Mika, Kum & $1,2 \mathrm{~cm}$ & $3,2 \mathrm{~cm}$ & $1,8 \mathrm{~cm}$ & Rulet & Beyaz \\
\hline D-3 & 7.5 YR $8 / 1$ & Mika, Kum & $1 \mathrm{~cm}$ & $2,8 \mathrm{~cm}$ & $2,3 \mathrm{~cm}$ & Rulet & Beyaz \\
\hline D-4 & $2.5 \mathrm{YR} 5 / 6$ & $\begin{array}{c}\text { Mika, } \\
\text { Kireç, Kum }\end{array}$ & $1,6 \mathrm{~cm}$ & $4 \mathrm{~cm}$ & $2,9 \mathrm{~cm}$ & $\begin{array}{c}\text { Kazıma, } \\
\text { Kalıp }\end{array}$ & Kirmızı \\
\hline D-5 & $2.5 \mathrm{YR} \mathrm{5/6}$ & Mika, Kum & $1,5 \mathrm{~cm}$ & $3,2 \mathrm{~cm}$ & $3,1 \mathrm{~cm}$ & $\begin{array}{c}\text { Kazıma, } \\
\text { Rulet }\end{array}$ & Kırmızı \\
\hline D-6 & 10 YR 8/1 & $\begin{array}{c}\text { Kireç, Kum, } \\
\text { Şamot }\end{array}$ & $0,7 \mathrm{~cm}$ & $3,2 \mathrm{~cm}$ & $1,6 \mathrm{~cm}$ & Rulet & Beyaz \\
\hline D-7 & 2.5 Y $3 / 1$ & Mika, Kireç & $0,9 \mathrm{~cm}$ & $3 \mathrm{~cm}$ & $1,9 \mathrm{~cm}$ & Bask1 & \\
\hline D-8 & 2.5 Y $5 / 1$ & $\begin{array}{c}\text { Mika, } \\
\text { Kireç, Kum }\end{array}$ & $1,3 \mathrm{~cm}$ & $2,8 \mathrm{~cm}$ & $2 \mathrm{~cm}$ & Bask1 & Beyaz \\
\hline D-9 & $10 \mathrm{YR} 8 / 2$ & $\begin{array}{c}\text { Mika, Kum, } \\
\text { Şamot }\end{array}$ & $1,4 \mathrm{~cm}$ & $3,4 \mathrm{~cm}$ & $2,3 \mathrm{~cm}$ & Bask1 & Kırmizı \\
\hline D-10 & 10 YR $8 / 2$ & $\begin{array}{c}\text { Mika, } \\
\text { Kireç, Kum }\end{array}$ & $1,3 \mathrm{~cm}$ & $2,7 \mathrm{~cm}$ & $2,1 \mathrm{~cm}$ & Kalıp & Beyaz \\
\hline D-11 & 10 YR $8 / 2$ & Mika, Kum & $1,3 \mathrm{~cm}$ & $4,3 \mathrm{~cm}$ & $2,4 \mathrm{~cm}$ & Kalıp, Rulet & Beyaz \\
\hline D-12 & 10 YR 8/2 & $\begin{array}{c}\text { Mika, } \\
\text { Kireç, Kum }\end{array}$ & $1,7 \mathrm{~cm}$ & $4 \mathrm{~cm}$ & $2,8 \mathrm{~cm}$ & $\begin{array}{l}\text { Kalıp, } \\
\text { Bask1 }\end{array}$ & Kırmızı \\
\hline
\end{tabular}

Közlük/Köz Kabı: Küçük parçalar hâlindeki közlerin seramik hamurundan yapılmış bu obje içerisine yerleştirildiği ve tütün içecek kişilerin tütünlerini buradan aldıkları közle yaktıkları düşünülmektedir. (G. 14) Parçanın iç kısmında mevcut olan yanmış kömür tozları ve ağız kısmında yoğun yanık izleri bulunması da kabın köz dağıtım amacıyla kullanıldığını göstermektedir. Lale veya zambak formlu lülelerle benzer forma sahip olan köz kabının tam formu ve kaidesinin olup olmadı̆̆ ise anlaşılamamaktadır. Hamur yapısı, seramik hamurlarına benzer şekilde büyük boyutlu, çok katkılı ve oldukça iyi pişmiş sert şekildedir. Köz kabı olduğu düşünülen obje 19. yüzyıla tarihlendirilmektedir. (T. 14) 


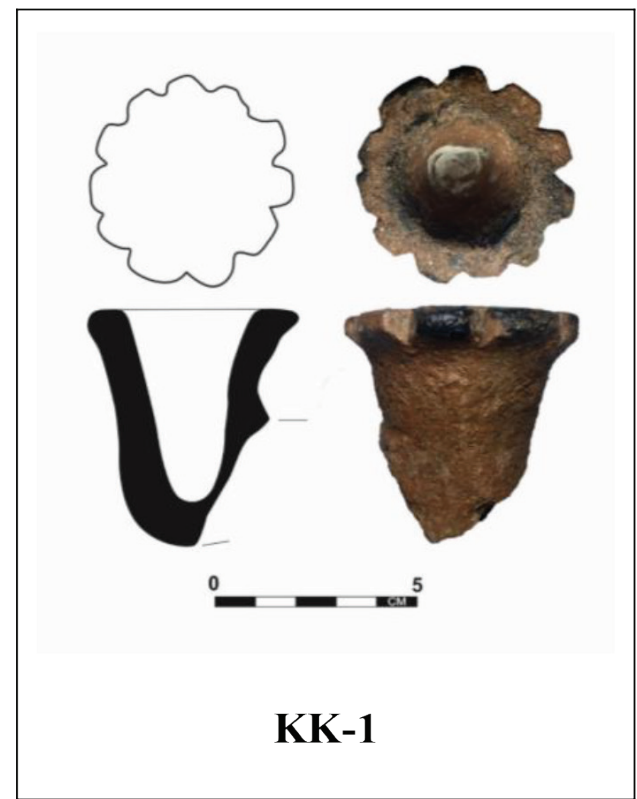

G. 14. Köz Kabı (?) (Korkmaz Şen, Yunus Emre Karasu, 2018)

Tablo 14

Köz Kabı (?) Özellikleri (Korkmaz Şen, Yunus Emre Karasu, 2018)

\begin{tabular}{|c|c|c|c|c|}
\hline No & Hamur Rengi & Katkı & Ăğı Çapı & Yükseklik \\
\hline KK-1 & 2.5 YR 6/6 & Mika, Kireç, Kum & $4 \mathrm{~cm}$ & $5,8 \mathrm{~cm}$ \\
\hline
\end{tabular}

\section{Bezeme Özellikleri}

Lülelerde görülen bezemeler ait olduğu kültür ve dönemin beğeni anlayışını önemli ölçüde yansıtır. Kazıma, oyma, rulet, baskı ve kalıpla bezeme gibi farklı teknikler kullanılan lüleler Anadolu ve çevresinde yapılan hemen hemen bütün kazı çalışmalarında görülmektedir. Üretimine dair ise somut veriler oldukça sınırlı olup ticaretle bölgeler arası dolaşımının sağlandığı tahmin edilmektedir. Ayrıca üretim yerlerinin büyük kısmı henüz bilinmemektedir. Bitlis Kalesi'nde siyah renkli perdahlı lülelere ait yarı mamul olduğu düşünülen parçaların bulunması bu grup örneklerin yerel üretim olabileceğine işaret etmektedir. Bitlis Kalesi'nde ele geçirilen yerel olabilecek siyah renkli örnekler daha sınırlı ve tek düze bir bezeme anlayışına sahiptir. Bu lülelerde rulet, baskı, kazıma ve kalıp teknikleriyle yapılmış bezemeler küçük değişikliklerle lüle yüzeyine uygulanmıştır. Aynı zamanda bu örneklerin form olarak neredeyse tamamının süzgeçli olduğu görülmektedir. 2019 yılında çanak kısmı içerisinde tütün bulunan birkaç lülenin bulunması bu örneklerin büyük ölçüde tütün içmek için kullanıldığını gösterir. Kazı çalışmalarında ele geçirilen diğer lülelerin ise bölgeye ithal olarak geldiği düşünülmektedir. Belirli merkezlerde yapıldığı düşünülen ve Anadolu'nun 
hemen hemen her bölgesinde karşılaşılan 17-18. yüzyıl beyaz astarlı ve 19. yüzyıl kırmızı astarlı örnekler ise bölgeye muhtemelen ticaretle gelmiştir. Daha ince işçilikli ve kaliteli olduğu görülen bu lülelerin yaygın dağılımı İstanbul başta olmak üzere büyük üretim merkezlerine işaret etmektedir. Ayrıca farklı bölgelerin yerel üretim lülelerinin bölgeler arası ticaretinin yapıldığı da düşünülmektedir. Bitlis Kalesi yerel üretim lülelerde sade ve ağırlıklı olarak geometrik; ithal örneklerde ise oldukça girift şekilde bitkisel, geometrik, figürlü bezemeler hâkimdir. Yerel üretim olduğu düşünülen seramiklerin ithal örneklere göre sayıca çokluğu bu lülelerin fiyat olarak daha ucuz olabileceğini ve yerel halk tarafından beğenilerek kullanıldığını göstermektedir. Ayrıca Bitlis Kalesi'nde 2018 yılında kazı çalışması yapılan açmalarda ve daha önceki yıllarda yapılan kazılarda da benzer lüleler ele geçirilmiştir. 2018 yılı açmalarında lüle buluntu sayısının oldukça fazla olduğu görülmektedir. Form ve bezeme açısından çeşitlilik görülen ithal örnekler Bitlis' in ticaret açısından oldukça hareketli bir bölge olduğuna da göstermektedir.

\section{Sonuç}

Bitlis Kalesinde 2018 yılı kazı çalışmalarında P ve R 14-15 olarak isimlendirilen iki açmada ve bir sondajda kazı çalışması yapılmıştır. Mekânların bulunduğu bu her iki açmada lüle buluntuları dışında kahve fincanı, seramik parçaları, metal objeler ve sikkeler ele geçirilmiştir. Günlük yaşama ait çok sayıda buluntuya ulaşılan bu mekânın kamusal alan olarak kullanıldığı düşünülmektedir. Osmanlı döneminde hamamdan çıkan kişilerin sıklıkla kahvehanelere gittikleri bilinmektedir. Özellikle lüle ile kahve fincanlarının yoğun olarak bulunması kalenin merkezinde yer alan hamamın hemen güneyinde bulunan bu mekânların kahvehane olarak kullanılmış olabileceğini göstermektedir. Bitlis Kalesi içerisinde günümüze kadar yapılan kazı çalışmalarında saray olduğu düşünülen bir mekân ve hamama ulaşılmıştır. Harçsız kuru duvarlardan yapılmış bu mekânın ise 18-19. yüzyıla ait olduğu düşünülmektedir.

Kazı çalışmaları yapılan açmalarda toprak örtüsünden yaklaşık $20 \mathrm{~cm}$ kazıldıktan hemen sonra dış yüzeyi siyah renkli perdahlı süzgeçli, basık yuvarlak çanaklı lüleler ile büyük boyutlu, kırmızı astarlı, perdahlı disk kaideli ve lale çanaklı lüleler bulunmaya başlanmış, böylece son dönem Osmanlı yerleşimi olan bu kısımdan ele geçirilen lüle buluntuları kalede son yerleşimin olduğu bilinen 19. yüzyıla tarihlendirilmiştir. İngiliz konsolos J. Brant'ın raporlarında da 1836 yılında kalenin kullanımın tamamen terk edildiği belirtilmektedir. ${ }^{60}$ Bu lülelerin 19. yüzyıla tarihlendirmesindeki sebep farklı bölgelerdeki benzer örnekler ile 1810-1811 tarihli II. Mahmut dönemine ait bir sikkeden sonra bu lüle buluntularına rastlanmamasıdır. Torba biçimli çanaklı, karina1, basık yuvarlak çanaklı lülelerle birlikte 1701-1702 tarihli II. Mustafa, 1737-1741

60 Korkmaz Şen ve Fatih Gencer, “İngiliz Konsolos J. Brant’ın Raporlarına Yansıyan Tarihi Eserler (Doğu Anadolu Bölgesi 1836-1852)", Yaşar Erdemir'e Armağan: Sanat Tarihi Yazıları (Konya: LiteraTürk Academia, 2019), 609-635. 
tarihli I. Mahmut, 1788 tarihli I. Abdülhamit dönemi sikkelerinin de ele geçirilmesi bu lülelerin ağırlıklı olarak 18. yüzyıla ait olduğunu göstermektedir. Ancak bu lüle formları içerisinde kirli beyaz tonlarda hamur rengine sahip lüleler diğer lüle buluntularından daha derinde, ağırlıklı olarak sondaj yapılan kısımda ele geçirilmiş olup bu lülelerle birlikte bulunan sikkelerin korozyon sebebiyle okunamaması nedeniyle 17. yüzyıl-18. yüzyılın ilk çeyreği (?) arasına ait oldukları düşünülmektedir. ${ }^{61}$ Lülelerle birlikte sikkelerinde ele geçirilmesi tarihlendirme için önemli veriler olmakla birlikte sikkelerin birbirine oldukça yakın şekilde bulunması ve korozyon sebebiyle çoğunun okunamaması lülelerin daha net tarihlendirilmesini zorlaştırmaktadır. Sikkelerin yanı sıra ele geçirilen çok sayıda kahve fincanı da mevcut verileri desteklemektedir. Siyah renkli lüle buluntuları dışındaki diğer örneklerin gerek form gerekse süsleme özellikleri bakımından benzer örneklerinin Anadolu'da ve Anadolu dışında yaygın olarak görülmesi, Bitlis Kalesi'nde ele geçen 17-19. yüzyıllara tarihlenen bu örneklerin ithal olarak ticaretle bölgeye geldiğini düşündürmektedir. Yarı mamul örnekleri bulunan siyah renkli lülelerin ise yerel üretim olduğu anlaşılmaktadır. Bitlis Kalesi'nde ilerleyen yıllarda yapılacak olan kazı çalışmaları alanın ve özellikle lülelerin stratigrafik verilerle birlikte daha kapsamlı değerlendirilmesine önemli katkı sağlayacaktır.

Hakem Değerlendirmesi: Dış bağımsız.

Çıkar Çatışması: Yazarlar çıkar çatışması bildirmemiştir.

Finansal Destek: Yazarlar bu çalışma için finansal destek almadığını beyan etmiştir.

Teşekkür: Ahlat Müze Müdürü Mikail Erçek ve Bakanlık temsilcisi uzman arkeolog Azat Örmek'e yardımlarından dolayı teşekkür ederiz.

Peer-review: Externally peer-reviewed.

Conflict of Interest: The authors have no conflict of interest to declare.

Grant Support: The authors declared that this study has received no financial support.

Acknowledgement: We thank to Ahlat Museum Director Mikail Erçek and Ministry Representative Expert Archaeologist Azat Örmek for their help.

\section{Kaynakça/References}

Abdülaziz Bey. Osmanlı Âdet, Merasim ve Tabirleri: Toplum Hayatı. Yay. Haz. Kazım Arısan ve Duygu Arısan Günay, İstanbul: Türkiye Ekonomik ve Toplumsal Tarih Vakfi, 1995.

Altınsapan, Erol. “2002 Yılı Bilecik Osmanlı Dönemi Çarşı Alanı Kazısı”. 25. Kazı Sonuçları Toplantısı. 2. cilt. Ankara: Kültür ve Turizm Bakanlığı Yayınları, 2004, 259-266.

Arık, M. Oluş. Bitlis Yapılarında Selçuklu Rönesansı. Ankara: Selçuklu Tarih ve Medeniyet Enstitüsü, 1971.

Ayhan, Gökben. "Hasankeyf Kazısı Lüle Buluntularının Değerlendirilmesi”. Ege Üniversitesi Edebiyat Fakültesi Sanat Tarihi Dergisi XIX/1 (2010): 1-22.

Ayhan, Gökben. “Smyrna Antik Kenti Kazıları 2007-2008 Y1lı Lüle Buluntuları”. Ege Üniversitesi Edebiyat Fakültesi Sanat Tarihi Dergisi XVIII/2 (2009): 1-22.

61 Katalog B-7, 10, 16; D-6, 11; T-2 numaralı lüleler 1701-1702 tarihli II. Mustafa dönemi sikkelerinden daha derinde ele geçirilmiş olup az gözenekli sık1, temiz hamurlu ve daha küçük formludur. 
Ayhan, Gökben. "An Evaluation on Tobacco Pipes Usage in the Tokat Region: In the Light of Tobacco Pipe Findings of Komana Excavation”. Komana Small Finds. Ed. D. Burcu Erciyas ve Meryem Acara Eser, İstanbul: Ege Yayınları, 2019, 347-383.

Ayhan, Gökben. “Ayasuluk İç Kalesi "Süzgeç Çanaklı” ve "Kaideli Süzgeç Çanaklı” Lüle Buluntuları”. Mustafa Büyükkolancı’ya Armağan. Ed. Celal Şimşek, Bahadır Duman ve Erim Konakç1. İstanbul: Ege Yayınları, 2015, 41-53.

Ayhan, Gökben. "Başur Höyük Kazısı Lüle Buluntuları". XIII. Ortaçağ ve Türk Dönemi Kazıları ve Sanat Tarihi Araştırmaları Sempozyumu Bildirileri (14-16 Ekim 2009), Denizli: Pamukkale Üniversitesi, 2010, 49-57.

Ayhan, Gökben. "Hasankeyf Kazısı Lüle Buluntuları”. Doktora tezi, Ege Üniversitesi, 2011.

Aytaç, İsmail. "Harput İç Kale Kazılarında 2015-2016 Yıllarında Bulunan Tütün Lülelerinin Değerlendirilmesi”. Yaşar Erdemir'e Armağan: Sanat Tarihi Yazıları. Konya: LiteraTürk Academia, 2019, 567-608.

Bakla, Erdinç. Tophane Lüleciliği, İstanbul: Dışbank Yayınları, 1993.

Baş, Gülsen. Bitlis Kalesi Arkeolojik Kazı Çalışmaları (2011-2015). İstanbul: Ege Yayınları, 2018.

BOA, MVL, 954-58 (H. 1278/M.1861)

Cengiz, Aysun. "Edirne Yeni Saray Kazılarında Ele Geçen Lüleler”. Yüksek Lisans tezi, Gazi Üniversitesi, 2011.

Çaycı, Ahmet ve Zekeriya Şimşir. "Gevale Kalesi 2015 Yılı Arkeolojik Kazı Çalışmaları”, XX. Uluslararası Ortaçağ ve Türk Dönemi Kazıları ve Sanat Tarihi Araştırmaları Sempozyumu Bildirileri (02-05 Kasım 2016). 1. cilt. Sakarya: Sakarya Üniversitesi, 2017, 37-48.

Daş, Ertan. “Alaşehir Kurşunlu Han Kazı ve Temizlik Çalışmaları”. XIII. Ortaçağ ve Türk Dönemi Kazıları ve Sanat Tarihi Araştırmaları Sempozyumu Bildirileri (14-16 Ekim 2009). Denizli: Pamukkale Üniversitesi, 2010, 197-212.

Erciyas, D. Burcu ve Mustafa N. Tatbul. "Anadolu'da Ortaçağ Kazıları ve Komana”. 37. Kazı Sonuçları Toplantısı (11-15 Mayıs 2015, Erzurum). 2. cilt. Ankara: Kültür ve Turizm Bakanlığ1 Yayınları, 2016, 611-626.

Fındık, Ebru Fatma. “Ay Işığında Tütün Seremonisi-Osmanlı Kırsalında Tütün Kullanımının Kanıtları: Aziz Nikolaos Kilisesi Kazıları Lüle ve Nargile Buluntuları”. Cedrus: The Journal of Mcri IV (2016): 373-392.

Gök Gürhan, Sevinç. “Akşehir Taş Medrese Müzesi’ndeki Türk Dönemi Seramikleri (2000-2001 Anıt Meydan'da Yapılan Kurtarma Kazısı Seramikleri)”. Doktora tezi, Ege Üniversitesi, 2007.

İnanan, Filiz ve Derya Şahin. “Arkeopark-Osmanlı Lüleleri Osmanlı'da Tütün Keyfi”. Uludağ Üniversitesi Fen-Edebiyat Fakültesi Sosyal Bilimler Dergisi 18/32 (2017): 33-54.

Kalayc1, Mehmet ve Eyüp Öztürk. “18. Yüzy1l Osmanlı Coğrafyasında Tütünün Sosyo-Kültürel Zeminine Dair Bir Metin: Ebu Sehl Nu'man Efendi ve Tahlılu'd-Duhan Adlı Risalesi”. Ankara Üniversitesi İlahiyat Fakültesi Dergisi 58/1 (2017): 1-45.

Kırl1, Cengiz ve Betül Başaran. "18. Yüzyıl Sonlarında Osmanlı Esnafı”, Osmanlı'dan Cumhuriyet'e Esnaf ve Ticaret. Der. Fatmagül Demirel. İstanbul: Tarih Vakfi Yurt Yayınları, 2012, 7-20.

Konyar, H. Banu, Ahmet Vefa Çobanoğlu ve Ayşe Denknalbant Çobanoğlu. "Eski Van Şehri, Kalesi ve Höyügü Kazıları Eski Van Şehri Alanı 2013 Yılı Çalışmaları”. Uluslararası XVIII. Ortaçă̆ ve Türk Dönemi Kazıları ve Sanat Tarihi Araştırmaları Sempozyumu Bildirileri (22-25 Ekim 2014). Aydın: Efeler Belediyesi Kültür Yayınları, 2017, 375-387. 
Lewis, Raphaela. Osmanlı Türkiyesinde Gündelik Hayat (âdetler ve gelenekler). Çev. Mefkure Poroy. İstanbul: Doğan Kardeş Yayınları, 1973.

Pektaş, Kadir. "Bitlis Kale Kazısı 2006 Yılı Çalışmaları". 29. Kazı Sonuçları Toplantısı (28 Mayıs-1 Haziran 2007). 1. cilt. Kocaeli: Kültür ve Turizm Bakanlığı Yayınları, 2008, 245-262.

Pektaş, Kadir. "Bitlis Kale Kazısı 2007 Yılı Çalışmaları". 30. Kazı Sonuçları Toplantısı (26-30 Mayıs 2008). 4. cilt. Ankara: Kültür ve Turizm Bakanlığı Yayınları, 2009, 317-326.

Pektaş, Kadir. "Bitlis Kale Kazısı 2008”. 31. Kazı Sonuçları Toplantısı (25-29 Mayıs 2009). 4. cilt. Denizli: Kültür ve Turizm Bakanlığı Yayınları, 2010, 85-100.

Pektaş, Kadir. "Bitlis Kalesi 2009 Yılı Kazısı”. 32. Kazı Sonuçları Toplantısı (24-28 Mayıs 2010). 4. cilt. İstanbul: Kültür ve Turizm Bakanlığı Yayınları, 2011, 285-298.

Robinson, Rebecca. "Clay Tobacco Pipes From the Kerameikos”. Mitteilüngen 98 (1983): 265-285.

Saldırgan, Gizem. "Cizre İç Kale Kazısı Lüle Buluntuları”. I. Uluslararası Sosyal Bilimler Kongresi (31 Ocak-2 Şubat 2018). Kayseri: Kayseri Üniversitesi, 2018, 607-621.

Sevin, Veli, Necla Arslan Sevin ve Haydar Kalsen. Harput Kale Mahallesinde Osmanlı Yaşamı. İstanbul: Ege Yayınları, 2011.

Shefer Mossensohn, Miri. Osmanlı Tıbbı: Tedavi ve Tıbbi Kurumları (1500-1700). Çev. Bülent Üçpunar. İstanbul: Kitap Yayınevi, 2014.

Simpson, John. “Late Ottoman Pipes From Jerusalem”. Excavations by K. M. Kenyon In Jerusalem 1961-1967. Vol. V. Oxford: Oxbow Books, 2008, 433-446.

Şen, Korkmaz ve Fatih Gencer. “İngiliz Konsolos J. Brant'ın Raporlarına Yansıyan Tarihi Eserler (Doğu Anadolu Bölgesi 1836-1852)". Yaşar Erdemir'e Armağan: Sanat Tarihi Yazıları. Konya: LiteraTürk Academia, 2019, 609-635.

Şen, Korkmaz ve Yunus Emre Karasu. "2018 Y11 Bitlis Kale Kazısı Kaideli, Süzgeçli Çanaklı Lüle Buluntuları”. Atatürk Üniversitesi Türkiyat Araştırmaları Enstitüsü Dergisi 65 (2019): 189-206.

Top, Mehmet ve Oktay Başak. "Hoşap Kalesi Kazısı 2011”. XVI. Ortaçă̆-Türk Dönemi Kazıları ve Sanat Tarihi Araştırmaları Sempozyumu Bildirileri (18-20 Ekim 2012). 2. cilt. Sivas: Cumhuriyet Üniversitesi, 2014, 749-763.

Top, Mehmet. "Hoşap Kalesi Kazısı (2007)”. IV. Uluslararası Van Gölü Havzası Sempozyumu (1721 Haziran 2008, Ahlat). Ankara: Bitlis Eren Üniversitesi, 2011, 112-116.

Tuncel, Metin. "Bitlis". TDV İslam Ansiklopedisi. 6. İstanbul: Türkiye Diyanet Vakfı Yayınları, 1992, 225-228.

Turan, Osman. Doğu Anadolu Türk Devletleri Tarihi. İstanbul: Ötüken Yayınları, 2001.

Uçar, Hasan. "Archaeological Proof of Enjoy at Tire Kutu Han: Clay Pipes”. Mediterranean Archaeology and Archaeometry 19/2 (2019): 119-134.

Uysal, Ali Osman. "Demirköy Fatih Dökümhanesi Kazısı Seramik Buluntuları”. Byzas 7, Çanak: Akdeniz Çevresindeki Arkeolojik Kazılarda Ele Geçen Antik ve Ortaçă̆ Seramiği ve Mimari Seramiği. İstanbul: Ege Yayınları, 2007, 545-558.

Ünal, Metin. “Tütünün Dört Yüz Y1l1”. Tütün Kitabı. Ed. Emine Gürsoy Naskali. İstanbul: Kitabevi, 2003, 17-33.

Vincenz, Anna De. “Ottoman Clay Tobacco Pipes From Ramla”. Atiqot 67 (2011): 43-53.

Yazıcı Metin, Nurcan. "Demirköy Fatih Dökümhanesi Kazısı Lüle Buluntuları (2010-2015)". Sanat Tarihi Ylllı̆̆ 28 (2019): 81-102. 
Yener, Azize. “Tütün Lüleleri ve Antalya-Kaleiçi'nde Bulunan Örnekler”. Arkeoloji ve Sanat 119 (2005): 94-113.

Y1lmaz, Fehmi. “İstanbul'da Tütüncü Esnafi”. Osmanlı'dan Cumhuriyet'e Esnaf ve Ticaret Der. Fatmagül Demirel. İstanbul: Tarih Vakfi Yurt Yayınları, 2012, 127-141.

Yılmaz, Fehmi. "Tütün Üzerine Düşünceler: Batıda ve Bizde”. Tütün Kitabı. Ed. Emine Gürsoy Naskali. İstanbul: Kitabevi, 2003, 3-16.

Yurttaş, Hüseyin, Haldun Özkan, Zerrin Köşklü, Süleyman Çiğdem, Nurşen Özkul Fındık ve Muhammet L. Kındığı11. "Kemah Kale Kazısı 2014 Yı1ı Çalışmaları”. Uluslararası XIX. Ortaçă̆ ve Türk Dönemi Kazıları ve Sanat Tarihi Araştırmaları Sempozyumu (21-24 Ekim 2015). II. cilt. Yay. Haz. Ceren Ünal ve Cengiz Gürbıyı. Ankara: Türk Tarih Kurumu Yayınları, 2019, 615-636. 